\title{
Twenty-Six Years of HIV science: an overview of anti-HIV drugs metabolism
}

\author{
Carolina Horta Andrade ${ }^{1, *}$, Lenis Medeiros de Freitas², Valéria de Oliveira ${ }^{3, *}$ \\ ${ }^{1}$ Laboratório de Modelagem Molecular, Faculdade de Farmácia, Universidade Federal de Goiás, ${ }^{2}$ Programa de Pós- \\ Graduação em Ciências Farmacêuticas, Faculdade de Farmácia, Universidade Federal de Goiás, ${ }^{3}$ Laboratório de \\ Bioconversão, Faculdade de Farmácia, Universidade Federal de Goiás
}

\begin{abstract}
From the identification of HIV as the agent causing AIDS, to the development of effective antiretroviral drugs, the scientific achievements in HIV research over the past twenty-six years have been formidable. Currently, there are twenty-five anti-HIV compounds which have been formally approved for clinical use in the treatment of AIDS. These compounds fall into six categories: nucleoside reverse transcriptase inhibitors (NRTIs), nucleotide reverse transcriptase inhibitors (NtRTIs), non-nucleoside reverse transcriptase inhibitors (NNRTIs), protease inhibitors (PIs), cell entry inhibitors or fusion inhibitors (FIs), co-receptor inhibitors (CRIs), and integrase inhibitors (INIs). Metabolism by the host organism is one of the most important determinants of the pharmacokinetic profile of a drug. Formation of active or toxic metabolites will also have an impact on the pharmacological and toxicological outcomes. Therefore, it is widely recognized that metabolism studies of a new chemical entity need to be addressed early in the drug discovery process. This paper describes an overview of the metabolism of currently available anti-HIV drugs.
\end{abstract}

Uniterms: AIDS/treatment. Drugs/anti-HIV. Drugs/metabolism. Antiretroviral drugs. Biotransformation.

Da identificação do HIV como o agente causador da AIDS, ao desenvolvimento de fármacos antirretrovirais eficazes, os avanços científicos na pesquisa sobre o HIV nos últimos vinte e seis anos foram marcantes. Atualmente, existem vinte e cinco fármacos anti-HIV formalmente aprovados pelo FDA para utilização clínica no tratamento da AIDS. Estes compostos são divididos em seis classes: inibidores nucleosídeos de transcriptase reversa (INTR), inibidores nucleotídeos de transcriptase reversa (INtTR), inibidores nãonucleosídeos de transcriptase reversa (INNTR), inibidores de protease (IP), inibidores da entrada celular ou inibidores de fusão (IF), inibidores de co-receptores (ICR) e inibidores de integrase (INI). O metabolismo consiste em um dos maiores determinantes do perfil farmacocinético de um fármaco. A formação de metabólitos ativos ou tóxicos terá impacto nas respostas farmacológicas ou toxicológicas do fármaco. Portanto, é amplamente reconhecido que estudos do metabolismo de uma nova entidade química devem ser realizados durante as fases iniciais do processo de desenvolvimento de fármacos. Este artigo descreve uma abordagem do metabolismo dos fármacos anti-HIV atualmente disponíveis na terapêutica.

Unitermos: AIDS/tratamento. Fármacos/anti-HIV. Fármacos/antirretrovirais. Fármacos/metabolismo. Biotransformação.

\section{INTRODUCTION}

The human immunodeficiency virus (HIV) has been established as the causative agent of the acquired immunodeficiency syndrome (AIDS) for over twenty-

\footnotetext{
*Correspondence: C.H. Andrade/V. de Oliveira, Laboratório de Modelagem Molecular (LabMol)/Laboratório de Bioconversão (LaBioCon), Faculdade de Farmácia, Universidade Federal de Goiás, Avenida Universitária c/ $1^{\mathrm{a}}$ Avenida, s/n, Setor Universitário, Caixa Postal 131, 74605-220 - Goiânia - GO, Brasil. E-mail: carolina@farmacia.ufg.br; valeria@farmacia.ufg.br
}

six years now (Barré-Sinoussi et al., 1983). During this time, an unprecedented success has been achieved in discovering anti-HIV drugs as reflected by the fact that there are now more drugs approved for the treatment of HIV than for all other viral infections put together (Mehellou, De Clercq, 2009). Despite this progress, the HIV pandemic remains one of the most serious challenges to global health and is set to continue to be one of the leading causes of death and disability in the world for decades to come (Vitoria et al., 2009). Since 1983, 
more than 60 million people have been infected with the virus, and more than 25 million people have died as a result (Cohen et al., 2008).

According to the World Health Organization (WHO), globally there were an estimated 33 million [30 million-36 million] people living with HIV in 2007. SubSaharan Africa remains the region most heavily affected by HIV, accounting for $67 \%$ of all people living with HIV and for $75 \%$ of AIDS deaths in 2007 (UNAIDS/WHO, 2008). In addition, according to the same report, it was estimated that almost 3 million HIV-infected people were receiving antiretroviral treatment in low- and middleincome countries, representing approximately $31 \%$ of the estimated 9.7 million people currently in need of treatment (UNAIDS/WHO, 2008).

Currently, there are twenty-five anti-HIV compounds that have been formally approved for clinical use in the treatment of AIDS. These compounds fall into six categories: nucleoside reverse transcriptase inhibitors (NRTIs), nucleotide reverse transcriptase inhibitors (NtRTIs), non-nucleoside reverse transcriptase inhibitors (NNRTIs), protease inhibitors (PIs), cell entry inhibitors or fusion inhibitors (FIs), co-receptor inhibitors (CRIs), and integrase inhibitors (INIs). Metabolism by the host organism is one of the most important determinants of the pharmacokinetic profile of a drug. Formation of active or toxic metabolites will have an impact on the pharmacological and toxicological outcomes. Therefore, it is widely recognized that metabolism studies of a new chemical entity need to be addressed early in the drug discovery process. This paper describes an overview of the metabolism of currently available anti-HIV drugs.

\section{ANTI-HIV DRUGS}

The antiretroviral therapy advanced with the elucidation of the HIV cycle of life. Zidovudine (3'-azido3'-deoxythymidine or AZT) $\left(\right.$ Retrovir $\left.^{\circledR}\right)$, a nucleoside analogue, was the first anti-HIV drug. AZT was originally synthesized as a potential anticancer drug by Horwitz in 1964 (Horwitz, Chua, Noel, 1964). In 1985, its anti-HIV activity was confirmed in vitro by a screening process using compounds that had previously been produced for others purposes (Fauci, 2003). AZT triphosphate acts by competitively inhibiting the utilization of thymidine triphosphate by reverse transcriptase (RT) of HIV-1 (Mitsuya et al., 1985). In 1987, AZT was approved by the United States Food and Drug Administration (FDA) and supplied by Burroughs-Wellcome Laboratories.

In 2009, twenty-six years after the discovery of HIV as causative agent of AIDS, no less than twenty-five anti-
HIV compounds have been formally approved for clinical use in the treatment of AIDS (Table I) (Adamson, Freed, 2009). These compounds fall into different categories, depending on the target within the HIV replicative cycle they interact with. In all, there are six categories: nucleoside reverse transcriptase inhibitors (NRTIs: zidovudine, didanosine, zalcitabine, stavudine, lamivudine, abacavir, emtricitabine), nucleotide reverse transcriptase inhibitors (NtRTIs: tenofovir), non-nucleoside reverse transcriptase inhibitors (NNRTIs: nevirapine, delavirdine, efavirenz, etravirine), protease inhibitors (PIs: saquinavir, ritonavir, indinavir, nelfinavir, amprenavir, lopinavir, atazanavir, fosamprenavir, tipranavir, darunavir), cell entry inhibitors or fusion inhibitors (FIs: enfuvirtide), co-receptor inhibitors (CRIs: maraviroc), and integrase inhibitors (INIs: raltegravir) (Mehellou, De Clercq, 2009).

Although treatment with antiviral agents has proven to be a highly effective way to improve the health and survival of infected individuals, the epidemic will continue to grow and there is an urgent need to develop new anti-HIV drugs.

\section{METABOLISM STUDIES}

Metabolism of a drug is one of the most important determinants of its pharmacokinetic properties. In most cases, metabolism leads to the inactivation of drugs. However, the metabolic transformation of a xenobiotic can also sometimes lead to the generation of an active metabolite, which can be solely or partially responsible for the pharmacological response. In some instances, metabolic transformation can also produce reactive or toxic intermediates or metabolites, with potential toxicological implications (Kumar, Surapaneni, 2001). Hence, a good understanding of the metabolism of a new chemical entity is needed early in the drug discovery process.

Mammalian metabolism of xenobiotics is traditionally subdivided into Phase I and Phase II processes. In Phase I, oxidation, reduction, or hydrolysis results in the introduction of new functional groups. Phase II involves conjugation reactions, where a highly hydrophilic moiety such as sulfate or glucuronide is attached to make the compounds more water-soluble and to prepare for excretion through urine or bile (Kumar, Surapaneni, 2001; Lee, Obach, Fisher, 2003).

The most important group of Phase I enzymes is the cytochrome P450 (CYP) superfamily. About $90 \%$ of catalysis mediated by $\mathrm{P} 450$ is performed by the human isoforms: CYPs 1A2, 2C9, 2C19, 2D6, 2E1 and 3A4 (Guengerich, 2006). They include oxidation reactions, such as aromatic hydroxylation, aliphatic hydroxylation, 
$\mathrm{N}$-oxidation, oxidative desalkylation and epoxide formation (Omura, 1999).

Key Phase II enzymes include, for instance, uridine diphosphate-dependent glucuronosyltransferase (UGT), sulfotransferases and glutathione- $S$-transferase. Glucuronidation of small lipophilic molecules by UGTs is probably the most important Phase II process for the clearance of drugs. Consistent with its broad substrate profile, UGT exists as an enzyme superfamily. So far, 18 UGT proteins, which can be divided into two families, UGT1 and UGT2, have been identified (Mackenzie et al., 1997).

\section{Prediction of drug metabolism in humans}

\section{In vitro and in vivo extrapolation}

The ability to predict human pharmacokinetic from in vitro and in vivo models with a reasonable degree of accuracy (2.0-fold variation) is an ongoing challenge with many different approaches yielding varying degrees of success (Prakash, Vaz, 2009). Traditionally, in vivo drug metabolism studies have relied on the use of model systems to produce the expected human metabolites of drugs. Usually whole animal systems are used, especially

TABLE I - Approved antiretroviral drugs in the US and Europe

\begin{tabular}{|c|c|c|c|}
\hline Generic Name & Brand Name & Manufacturer & Date of FDA approval \\
\hline Zidovudine & Retrovir & GlaxoSmithKline & 19 March 1987 \\
\hline Didanosine & $\begin{array}{c}\text { Videx (tablet) } \\
\text { Videx EC (capsule) }\end{array}$ & $\begin{array}{l}\text { Bristol Myers-Squibb } \\
\text { Bristol Myers-Squibb }\end{array}$ & $\begin{array}{l}9 \text { October } 1991 \\
31 \text { October } 2000\end{array}$ \\
\hline Zalcitabine & Hivid & Hoffmann-La Roche & 19 June 1992 \\
\hline Stavudine & Zerit & Bristol Myers-Squibb & 24 June 1994 \\
\hline Lamivudine & Epivir & GlaxoSmithKline & 17 November 1995 \\
\hline Saquinavir & $\begin{array}{l}\text { Invirase (hard gel capsule) } \\
\text { Fortovase (soft gel capsule) }\end{array}$ & $\begin{array}{l}\text { Hoffmann-La Roche } \\
\text { Hoffmann-La Roche }\end{array}$ & $\begin{array}{l}6 \text { December } 1995 \\
7 \text { November } 1997\end{array}$ \\
\hline Ritonavir & Norvir & Abbott Laboratories & 1 March 1996 \\
\hline Indinavir & Crixivan & Merck & 13 March 1996 \\
\hline Nevirapine & Viramune & Boehringer Ingelheim & 21 June 1996 \\
\hline Nelfinavir & Viracept & Agouron Pharmaceuticals & 14 March 1997 \\
\hline Delavirdine & Rescriptor & Pfizer & 4 April 1997 \\
\hline Efavirenz & $\begin{array}{c}\text { Sustiva (US) } \\
\text { Stocrin (Europe) }\end{array}$ & $\begin{array}{l}\text { Bristol Myers- } \\
\text { Squibb Merck }\end{array}$ & $\begin{array}{l}17 \text { September } 1998 \\
17 \text { September } 1998\end{array}$ \\
\hline Abacavir & Ziagen & GlaxoSmithKline & 17 December 1998 \\
\hline Amprenavir & Agenerase & GlaxoSmithKline & 15 April 1999 \\
\hline Lopinavir + ritonavir & $\begin{array}{c}\text { Kaletra } \\
\text { Aluvia (developing world) }\end{array}$ & $\begin{array}{l}\text { Abbott Laboratories } \\
\text { Abbott Laboratories }\end{array}$ & $\begin{array}{l}15 \text { September } 2000 \\
15 \text { September } 2000\end{array}$ \\
\hline Tenofovir & Viread & Gilead Sciences & 26 October 2001 \\
\hline Enfuvirtide & Fuzeon & Hoffmann-La Roche \& Trimeris & 13 March 2003 \\
\hline Atazanavir & Reyataz & Bristol-Myers Squibb & 20 June 2003 \\
\hline Emtricitabine & Emtriva & Gilead Sciences & 2 July 2003 \\
\hline Fosamprenavir & $\begin{array}{l}\text { Lexiva (US) } \\
\text { Telzir (Europe) }\end{array}$ & $\begin{array}{l}\text { GlaxoSmithKline } \\
\text { GlaxoSmithKline }\end{array}$ & $\begin{array}{l}20 \text { October } 2003 \\
20 \text { October } 2003\end{array}$ \\
\hline Tipranavir & Aptivus & Boehringer Ingelheim & 22 June 2005 \\
\hline Darunavir & Prezista & Tibotec, Inc. & 23 June 2006 \\
\hline Maraviroc & $\begin{array}{l}\text { Celsentri (Europe) } \\
\text { Selzentry (US) }\end{array}$ & $\begin{array}{l}\text { Pfizer } \\
\text { Pfizer }\end{array}$ & $\begin{array}{l}18 \text { September } 2007 \\
18 \text { September } 2007\end{array}$ \\
\hline Raltegravir & Isentress & Merck \& Co., Inc. & 12 October 2007 \\
\hline Etravirine & Intelence & Tibotec Therapeutics & 18 January 2008 \\
\hline
\end{tabular}


small laboratory animal models like rat, dog, cat, guinea pig, rabbit etc. However, interspecies differences must be considered since there is no "perfect" animal model destined for extrapolation to the human model. In vitro studies are generally used to complement and specify the data obtained using perfused organs, tissue or cell cultures and microsomal preparations. Such methods suffer from a number of limitations, such as the cost of experimental animals, the ethical concerns and species variations (Asha, Vidyavathi, 2009; Collins, 2001).

Isolated perfused rat liver has the advantages of controlling blood and bile flows, ease of manipulation of the perfusion medium and the large number of perfusate samples that may be collected (Meijer, Swart, 1997). Instead, microsomal preparations are derived from endoplasmic reticulum after homogenization and centrifugation and present CYPs and UGTs. They are developed to predict metabolic clearance of the compound and drug-drug interactions, and are widely used for drug metabolism studies (Pelkonen et al., 2005).

Another important tool employed in drug metabolism is the application of human hepatocyte cultures, that present both Phase I and Phase II enzymes, representing a great model for biotransformation study mediated by P450, and allowing a good correlation with in vivo studies. On the other hand, the use of hepatocyte cultures is limited by the restricted availability of liver tissue (Li et al., 1997; Gomez-Lechon et al., 2004). Liver-derived HepG-2 and $\mathrm{BC} 2$ cell lines and lung-derived line A549 have the disadvantage of expressing few enzymes, restricting their metabolic capacity (Yoshitomi et al., 2001; Le Vee et al., 2006). However, the recent human hepatoma-derived cell line HepaRG has been shown to possess functions and morphological resemblance to normal human hepatocytes (Aninat et al., 2006).

The use of microorganisms as models of mammalian metabolism was introduced in the early 1970s by Smith and Rosazza (Smith, Rosazza, 1974, 1975). This method uses eukaryotic microorganisms to produce metabolites similar to mammals, since microbial transformation systems could closely mimic most of the Phase I transformations of drugs observed in mammals, mainly those catalyzed by cytochrome P450 (Azerad, 1999).

Compared with traditional methods, there are clearly a number of practical advantages in using microbial transformation as a model for drug metabolism, such as its chemo-, regio-, and stereoselectivity, impressive catalytic efficiency, and capability of accepting a wide range of complex molecules as substrates. In addition, it is conducive to easy scale up to produce sufficient amounts of metabolites for unambiguous structural determination, and to provide such metabolites as authentic standards (Zmijewski et al., 2006; Asha, Vidyavathi, 2009).

Therefore, it is a valuable tool in the production of molecules with improved, different or toxic activity originated by the fungal enzymatic biodiversity (Azerard, 1999; Asha, Vidyavathi, 2009). Recently, our laboratory has carried out a number of studies applying microbial models to study mammalian metabolism (Gomes et al., 2006; Pazzini et al., 2005, 2010; Carneiro et al., 2005, 2010; Dias et al., 2005; Costa et al., 2008; Braga et al., 2011).

\section{In silico Computational Tools}

In recent years, several in silico computational methods have become available for prediction of metabolism and pharmacokinetics of the NCEs and are increasingly becoming a part of the drug discovery process to select candidates with desirable ADME properties (Canavan, 2007; Afzelius et al., 2007; De Graff, Vermeulen, Feenstra, 2005). Mechanism-based quantum chemical calculations on substrates and the enzyme, pharmacophore modeling of ligands, and protein homology modeling in combination with automated docking and molecular dynamics simulations have been used to rationalize and predict ligand binding and formation of metabolites (Prakash, Vaz, 2009).

Moreover, the prediction of metabolites can be performed by means of large collections of transformation rules. A given compound is fragmented and then passed through all rules to identify putative metabolically labile sites. Expert systems and their databases, such as MetabolExpert (Darvas, 1988), META (Klopman, Dimayuga, Talafous, 1994), METEOR (Testa et al., 2005), MetaDrug (Ekins et al., 2006), and PK/DB (Moda et al., 2008), are examples of in silico methods used to predict drug biotransformation pathways and possible metabolites, that provide a ranked list of most likely metabolites.

Metasite (Cruciani et al., 2005) is a computational program for metabolite formation prediction, which combines structural information, by matching the structural complementarity of the substrate and the protein, and rule-based and reactivity methods.

The availability of more and more $3 \mathrm{D}$ protein structures of $\mathrm{P} 450$ paves the way for molecular modeling approaches that zoom in on the atomic details of enzymeligand interactions. Docking is the most commonly used structure-based method, able to predict the site of metabolism of the substrate based on which atoms are exposed or close to the catalytic centre (the heme iron) in order for metabolism to take place (Stjernschantz, Vermeulen, Oostenbrink, 2008). 


\section{ANTI-HIV DRUGS METABOLISM}

Since the discovery of antiretrovirals, metabolism studies of these drugs have been increasingly carried out, aiming to ensure their efficacy and safety and to explain their toxic effects (Li, Chan, 1999). This trend is graphically illustrated in Figure 1, which presents the number of publications about antiretrovirals metabolism, between 1987 and 2009, retrieved upon searching with the SciFinder engine.

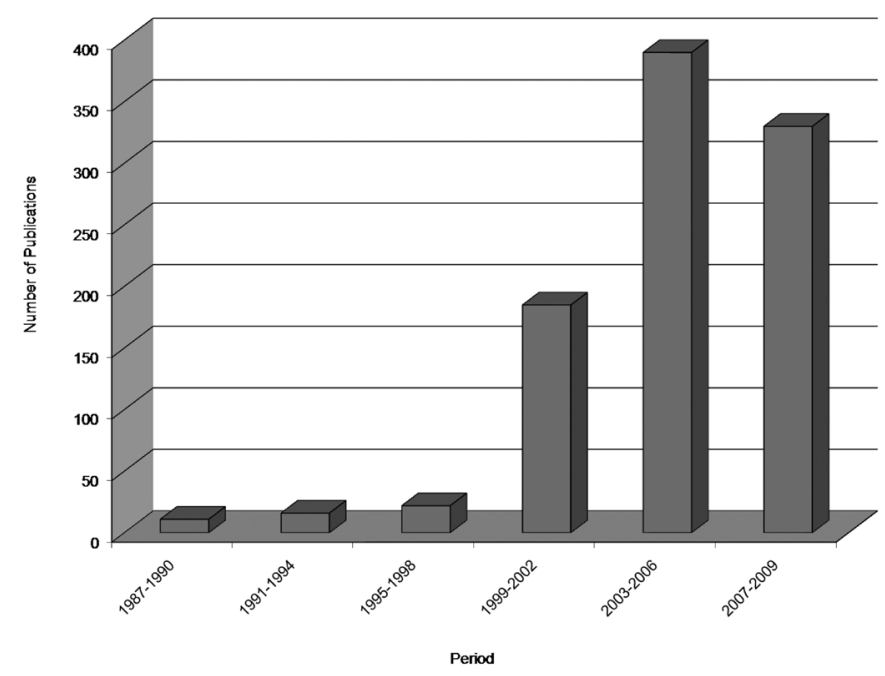

FIGURE 1 - Graphical representation of the increasing trend for number of anti-HIV drugs metabolism publications, from 1987 to October 2009 (data presented are those listed by SciFinder).

\section{Nucleoside Analogue Reverse Transcriptase Inhibitors (NRTIs)}

The reverse transcriptase (RT) of HIV is actually the target for three classes of inhibitors: nucleoside RT inhibitors (NRTIs), nucleotide RT inhibitors (NtRTIs) and non-nucleoside RT inhibitors (NNRTIs). The NRTIs and NtRTIs interact with the catalytic site (that is the substratebinding site) of the enzyme, whereas the NNRTIs interact with an allosteric site located a short distance from the catalytic site (De Clercq, 2007).

For the NRTIs and NtRTIs to interact with the substrate-binding site they need to be phosphorylated to the triphosphate and diphosphate forms, respectively. There are at present, seven NRTIs that have been formally approved for the treatment of HIV infections: zidovudine (AZT), didanosine (ddI), zalcitabine (ddC), stavudine (d4T), lamivudine (3TC), abacavir (ABC) and emtricitabine [(-)FTC]. All the NRTIs can be considered 2',3'-dideoxynucleoside $(\mathrm{ddN})$ analogues and act in a similar fashion. After they have been taken up as such by the cells, they are phos- phorylated to their 5'-mono-, 5'-di- and 5'-triphosphate (MP, DP and TP, respectively) form following the same mechanism: ddN $\rightarrow$ ddNMP $\rightarrow$ ddNDP $\rightarrow$ ddNTP, before the latter will then act as a competitive inhibitor/alternate substrate of the normal substrate dNTP (either dATP, dTTP, dGTP or dCTP) (Furman et al., 1986; De Clercq, 2007). As competitive inhibitor of the normal substrate, the ddNTP will inhibit incorporation of this substrate into the growing DNA chain; as alternate substrate it will be incorporated into this chain (as ddNMP), thereby acting as a chain terminator (since the ddNMP is missing the 3 '-hydroxyl group required for further chain elongation) (De Clercq, 2007).

Among the NRTIs, metabolism studies have been focused on zidovudine (AZT). There are three main metabolic pathways of AZT: intracellular phosphorylation, glucuronidation and reduction (Figure 2). The intracellular metabolism, which involves the formation of zidovudine5'-triphosphate (AZT-TP, 1), is limited in the last two steps of phosphorylation due to an inefficiency of the enzyme thymidine kinase to form zidovudine-5' -diphosphate (AZT-DP), leading to accumulation of zidovudine-5'monophosfate (AZT-MP) within the cell, and serving as a deposit for the formation of AZT-TP. High concentrations of AZT-MP inhibit the thymidylate kinase, decreasing the intracellular concentration of deoxythymidine-5'triphosphate and increasing the activity of antiretroviral. Furthermore, the accumulation of intracellular AZT-MP may be related to the toxicity observed during the use of AZT, mainly represented by hematological toxicity, likely caused by mitochondrial DNA polymerase $\gamma$ inhibition (Veal, Back, 1995).

AZT undergoes fast first-pass hepatic metabolism, producing zidovudine-5'-glucuronide (GAZT, 2), an inactive metabolite (Li, Chan, 1999). In studies using human microsomal preparations, it was observed that AZT's glucuronidation is independent of sex or age, but the polymorphism displayed by UGT2B7 isoform may contribute to the interindividual variations observed in plasma concentration of AZT and its conjugate metabolite (Court et al., 2003). However, these variations may be involved in the conjugation catalyzed by other isoforms, as well as the stage of intracellular AZT's phosphorylation, which implies a greater or lesser availability of substrate for hepatic metabolism. Also, according to studies on liver microsomes, the extent of metabolism of AZT by UGT can range from 60 to $75 \%$ in humans, while in rats it is only $10 \%$ (Naritomi et al., 2003 ) due to higher catalytic efficiency of these enzymes in the former (Trapnell et al., 1998).

The third metabolic pathway of AZT consists of its azido group reduction, probably mediated by both 


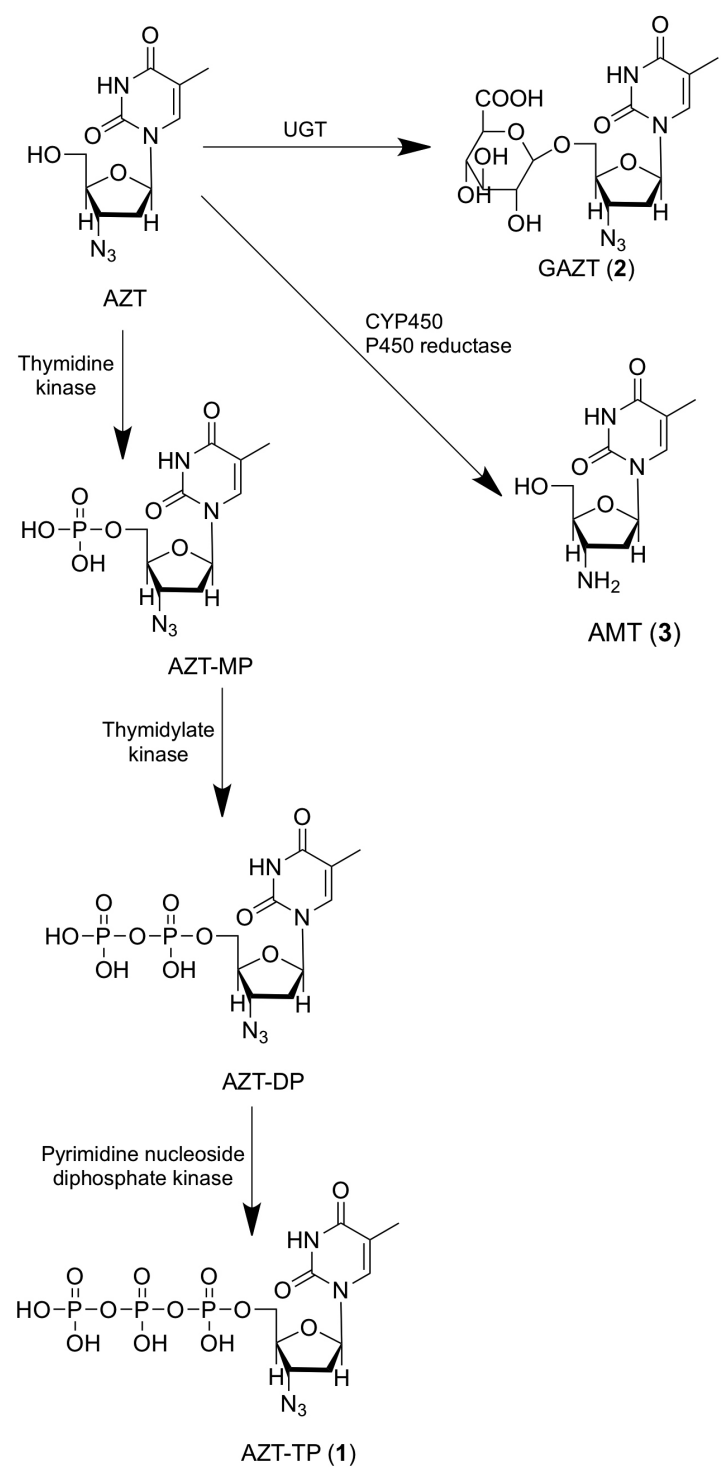

FIGURE 2 - Main metabolic routes of zidovudine in humans.

cytochrome P450 isoenzymes, NADPH-cytochrome $\mathrm{P} 450$ reductase and cytochrome b5 reductase, resulting in 3'-amino-3'-deoxythymidine (AMT, 3). In studies using rat hepatocytes and liver microsomes of rats and humans, the participation of the subfamilies CYP2B, CYP3A and CYP4A was observed in this reaction, evidenced by an increased formation of AMT through the use of inducers of these enzymes. The CYP2C9 isoform also appears to be involved in this process. These studies have also indicated that the AMT is five to seven times more toxic to the hematopoietic cells than AZT, confirming its role in the cytotoxicity of antiretroviral therapy observed in patients. In another similar study, the AMT glucuronide conjugate (GAMT), produced from the reduction of zidovudine-5'glucuronide, was found to discard the AMT as a substrate for UGT (Cretton et al., 1991).
AZT metabolism studies were also performed using microbial models obtaining derivatives not previously reported in the literature (Figure 3). Kruszewska and coworkers (2003) studied the bioconversion of AZT with an environmental bacterium, Stenotrophomonas maltophilia PCM 1942. After ten days of incubation, a hydroxylated metabolite at the C-2' deoxyribose ring (4) was produced with a yield of about $97 \%$ (Kruszewska et al., 2003). In our laboratory, biotransformation of AZT was performed using Cunninghamella echinulata ATCC 9244 as a catalyst (Nunes, 2008). This filamentous fungus strain is widely known for performing biotransformation reactions of a variety of compounds, similar to mammals, and is frequently employed in bioconversion processes. In our experiment, C. echinulata produced a glycosylated metabolite of AZT (5) (Figure 3) after seven days of incubation, under mild conditions of temperature and $\mathrm{pH}$, with a yield of about $46 \%$ (Nunes, 2008).

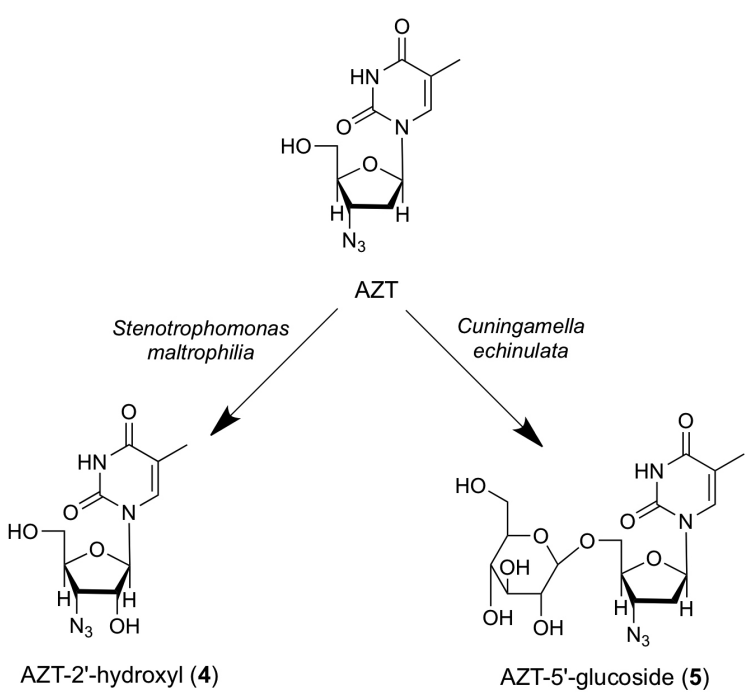

FIGURE 3 - Microbial metabolites of AZT: AZT-2'-hydroxyl (4) (Kruszewska et al., 2003) and AZT-5'-glucoside (5) (Nunes, 2008).

Didanosine (2', 3'-dideoxyinosine or ddI) (Figure 4 ) is first phosphorylated by 5 '-nucleotidase to form didanosine-5'-monophosfate (ddI-MP) in human lymphoid cells. Then, ddI-MP is converted to dideoxyadenosine-5' -monophosfate (ddA-MP) by adenylosuccinate synthetase and lyase, with subsequent phosphorylation to dideoxyadenosine-5' -triphosphate (ddA-TP) by adenylate kinase (miokinase), producing active metabolite (6) responsible for inhibiting viral reverse transcriptase. In another metabolic pathway, ddI is hydrolyzed by purine nucleoside phosphorylase, to release the sugar deoxyribose (7) and hypoxanthine (8), which is degraded into 
uric acid (9) and eliminated (Navé et al., 1994). In a study using beagle dogs, the following possible metabolites of didanosine were found in plasma and urine: allantoin, uric acid, hypoxanthine and xanthine (Kaul et al., 1993). Probably ddI is not metabolized by CYP450 isoforms, since studies using inducers of these enzymes showed no changed pharmacokinetic profile (Bruzzese et al., 1995).

Zalcitabine (2',3'-dideoxycytidine or ddC), as well as other nucleoside analogues, must be phosphorylated to dideoxycitidine-5' -triphosphate (ddC-TP) in the intracellular environment to become active (10) (Figure 5). The

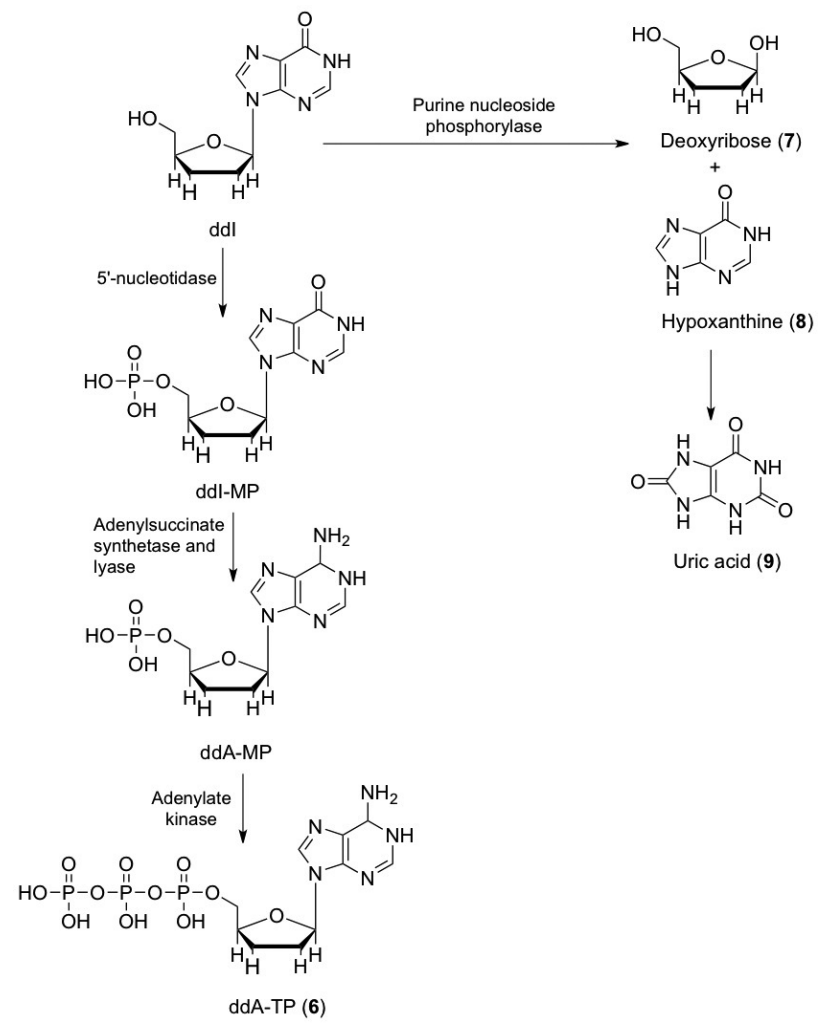

FIGURE 4 - Proposed metabolic pathways of didanosine. first stage of phosphorylation, with production of ddC-MP, seems to be inefficient due to a low affinity between $\mathrm{ddC}$ and the enzyme deoxycytidine kinase. In addition to the mono-, di- and triphosphate, the only reported metabolite of zalcitabine is dideoxyuridine, found in urine ( $\mathrm{Li}$, Chan, 1999).

Human metabolism of stavudine (2',3'-didehydro2',3'-dideoxythymidine or d4T) (Figure 6) has yet to be completely elucidated. Intracellularly, it is sequentially phosphorylated to produce its active form, stavudine-5' triphosphate (d4T-TP) (11). In a study using monkeys and isolated rat hepatocytes, the degradation of stavudine was detected in thymine (12) and the d4T-TP derivative, with subsequent production of beta aminoisobutyric acid (BAIBA) (13) (Cretton et al., 1993). The glucuronide metabolite (14) of stavudine was found in the urine of monkeys but has remained controversial (Schinazi, et al., 1990).

A recent study reported by our group (Freitas, 2009) described the metabolic profile of stavudine, applying in vivo, in vitro and in silico approaches. The bioconversion experiments with nine strains of filamentous fungi, detected one major metabolite, which was further identified as thymine (12). The in vivo study with Balb/c mice detected the same metabolite (thymine, 12), highlighting the strains used in this study as microbial models of stavudine metabolism (Figure 7). Unlike in vivo and in vitro experiments, the in silico study based upon the docking and molecular dynamics simulations of stavudine in complex with the active site of cytochrome P450 CYP3A4 structure, identified that the methyl group is the most probable site for the oxidation reaction mediated by CYP450 enzymes. It is likely that the in vivo and in vitro results described in this study must be mediated by enzymes other than CYP-450.

Lamivudine (3TC) (Figure 8) is another NRTI, whose intracellular phosphorylation occurs efficiently to produce its active metabolite, lamivudine-5' -triphosphate (3TC-TP) (15). There was no difference in the concen-

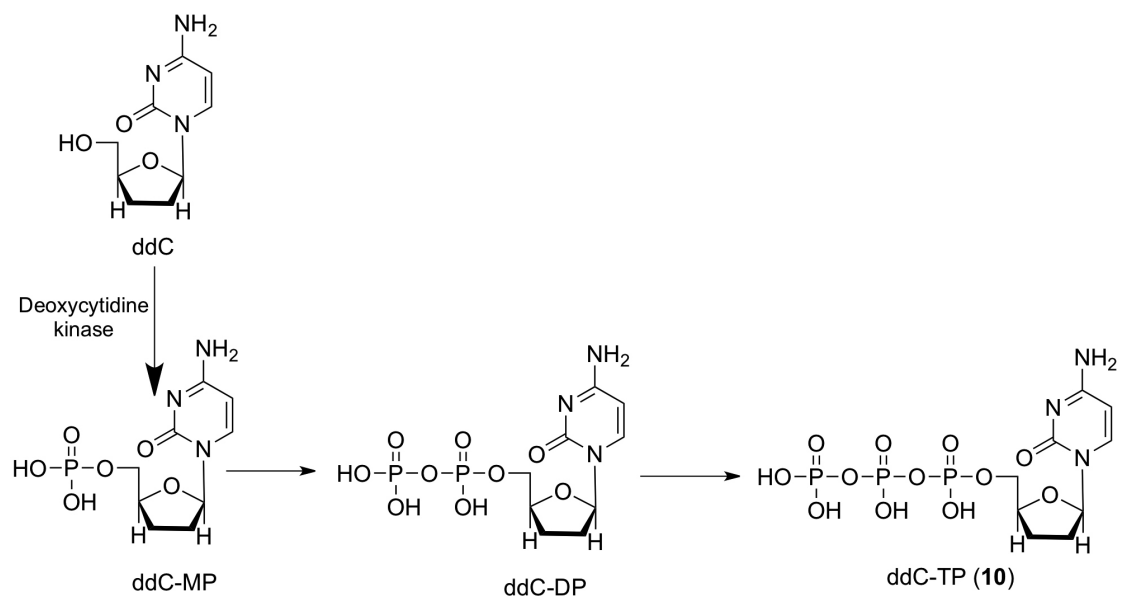

FIGURE 5 - Metabolic scheme for zalcitabine. 


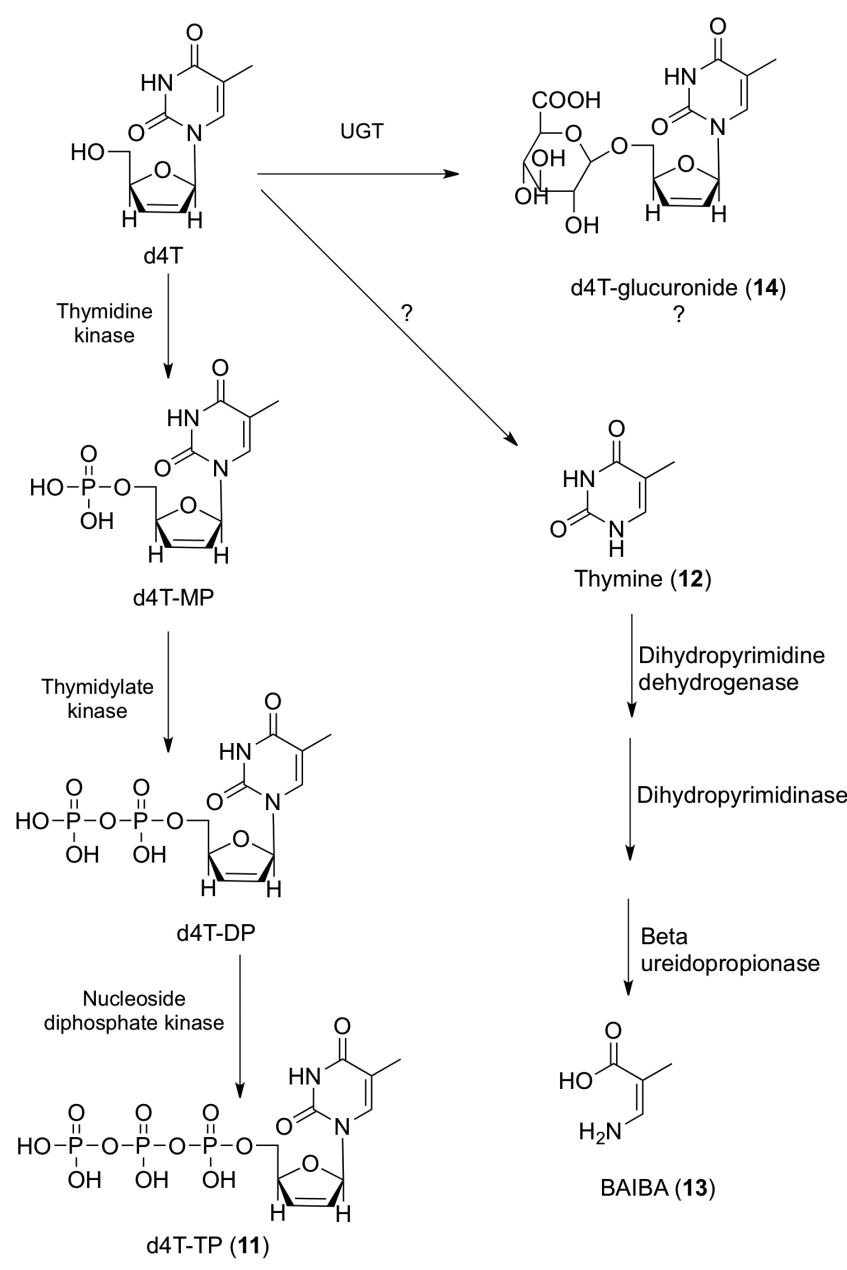

FIGURE 6 - Proposed metabolic routes of stavudine.

tration of 3TC and its pharmacokinetic profile in healthy individuals and patients with moderate to severe hepatic dysfunction, suggesting that lamivudine metabolism by liver enzymes is minimal (Johnson, Horak, Breuel, 1998).

Abacavir (ABC) (Figure 9), an analogue of 2'-deoxyguanosine, undergoes fast intracellular phosphorylation

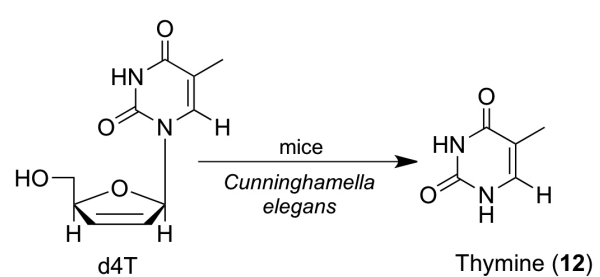

FIGURE 7 - Metabolism studies of stavudine by C. elegans and mice, producing the metabolite thymine (Freitas, 2009).

catalyzed by the enzyme adenosine phosphotransferase, producing its monophosphate form, which is then converted into the monophosphate form of carbovir (CBVMP) by a cytosolic deaminase. Subsequently, CBV-MP is converted into the di- and triphosphate form (16), the latter is another analogue of deoxyguanosine with potent inhibitory activity of viral reverse transcriptase (Faletto et al., 1997).

In addition, it also undergoes hepatic biotransformation in humans, mice and monkeys, producing two major metabolites, identified as 5'-carboxylate (17) and 5' -glucuronide derivatives (18), formed by cytosolic alcohol dehydrogenase (ADH) and UGT, respectively (Good et al., 1995; McDowell et al., 1999). In in vitro experiments with human liver microsomes, it was demonstrated that CYP450 enzymes appear to be involved in the metabolism of abacavir (Ravitch et al., 1998).

\section{Nucleotide Reverse Transcriptase Inhibitors (NtRTIS)}

NtRTIs should be clearly distinguished from the NRTIs as they are nucleotide analogues (not nucleoside analogues), which means they only need two (not three) phosphorylation steps to be converted to their active form. Most importantly, they contain a phosphonate group that<smiles></smiles>

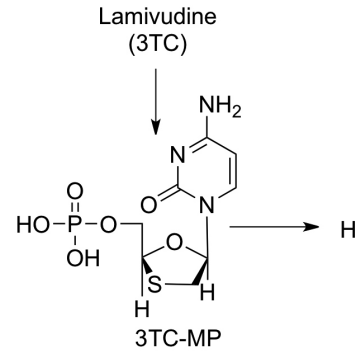

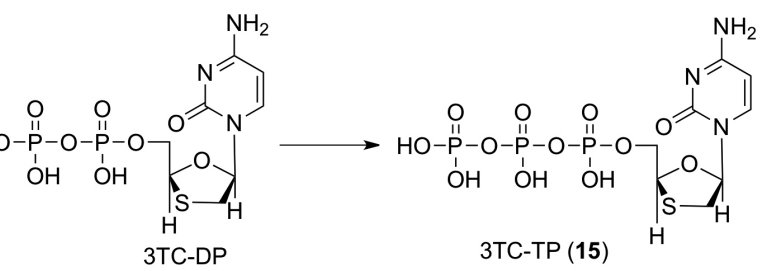

FIGURE 8 - Intracelular metabolism of lamivudine. 


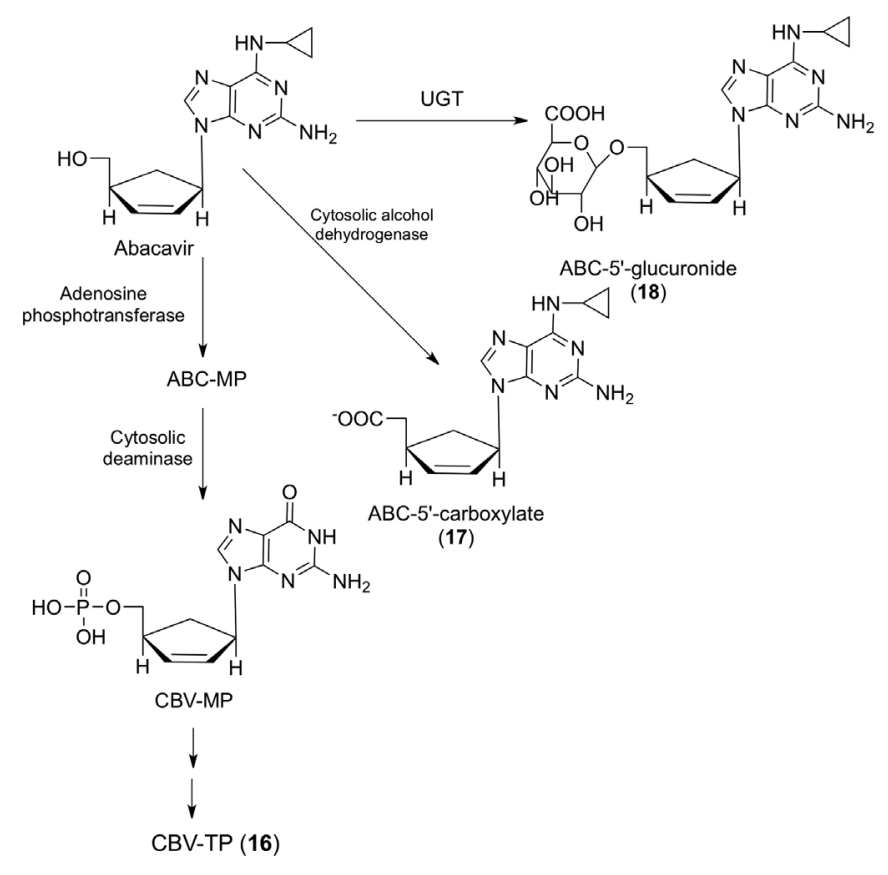

FIGURE 9 - Main metabolic pathways of abacavir in humans.

cannot be cleaved by hydrolases (esterases), which would make it more difficult to cleave off these compounds once incorporated at the 3'-terminal end, as compared to their regular nucleotide counterparts (i.e. AZTMP, ddAMP, ddCMP, etc.). The prototype of the NtRTIs, $(R)-9$-(2- phosphonomethoxypropyl) adenine (tenofovir) (Figure 10) was first described in 1993 (Balzarini et al., 1993) and is the only NtRTIs currently approved for use in patients suffering from HIV. Due to its limited oral bioavailability, tenofovir has been converted to its oral prodrug form, tenofovir disoproxil fumarate (TDF, Viread ${ }^{\circledR}$ ) and has become one of the most frequently prescribed drugs for the treatment of HIV infections (De Clercq, 2003). Since 2008, it has also been approved for the treatment of chronic hepatitis $B$ virus (HBV) infections. Tenofovir is metabolized intracellularly to its active metabolite, tenofovir diphosphate (19), which is a competitive inhibitor of HIV-1 RT that terminates the growing DNA chain. Phosphorilation to its diphosphate form can be achieved in one or two steps with the aid of 5-phosphoribosyl-1-pyrophosphonate (PRPP) synthetase (Balzarini et al., 1995) or AMP kinase (Merta et al., 1992), respectively (Figure 10).

\section{Non-nucleoside Reverse Transcriptase Inhibitors (NNRTIs)}

These compounds are noncompetitive inhibitors of HIV-1 RT, because they act differently compared with nucleoside analogues. They are mainly metabolized by the CYP3A subfamily of cytochrome P450 enzymes. Nevirapine (NVP) (Figure 11), for example, is capable of inducing its own metabolism mediated by CYP450 with production of several hydroxylated metabolites, with subsequent glucuronidation. These derivatives were found in urine and feces of human and animals (dog, mouse, rat, chimpanzee, rabbit and monkey), after oral administration of nevirapine, and identified as 2-hydroxy-nevirepine (20), 3-hydroxy-nevirapine (21), 8-hydroxy-nevirapine (22), 12-hydroxy-nevirapine (23), their respective glucuronide conjugates (24-27), and 4-carboxy-nevirapine (28), formed by secondary oxidation of $\mathbf{2 3}$ (Riska et al., 1999a, b). In experiments with human liver microsomes, it was observed that CYP3A and CYP2B6 are responsible for 2and 3-hydroxy-nevirapine production, respectively, while the formation of 8-and 12-hydroxi-nevirapine is mediated by several enzymes, primarily CYP3A4 and CYP2D6 (Erickson et al., 1999).

Delavirdine (Figure 12) is another NNRTI, which produces various metabolites in rats (Chang et al., 1997a), mice (Chang et al., 1997b) and monkeys (Chang et al., 1997c) through oxidation reactions catalyzed mainly by CYP450. An $N$-desalkylation reaction produces the desalkyl delavirdine metabolite (29), with subsequent sulfation (30), while hydroxylation at C-6' position of the pyrimidinic ring produces 6'-hydroxydelavirdine (31), followed by glucuronidation to form the

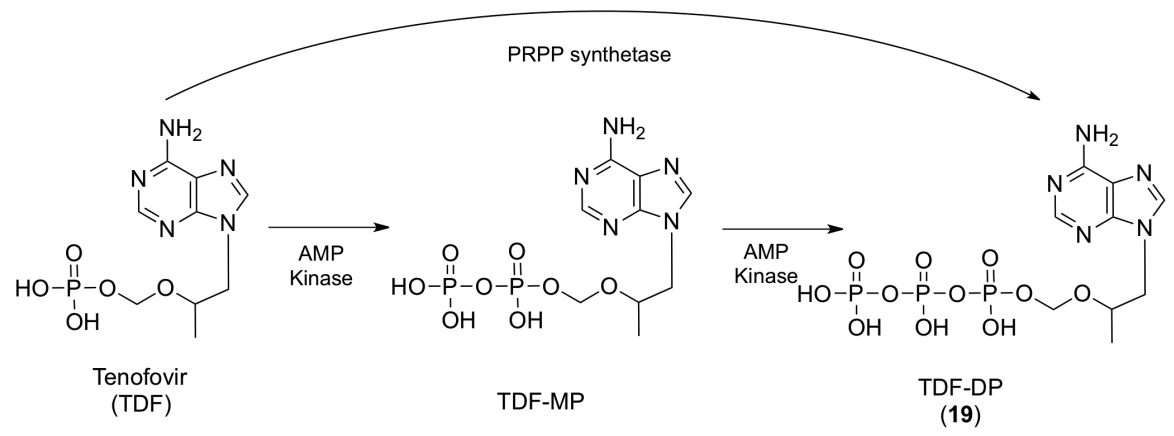

FIGURE 10 - Metabolism of tenofovir. 


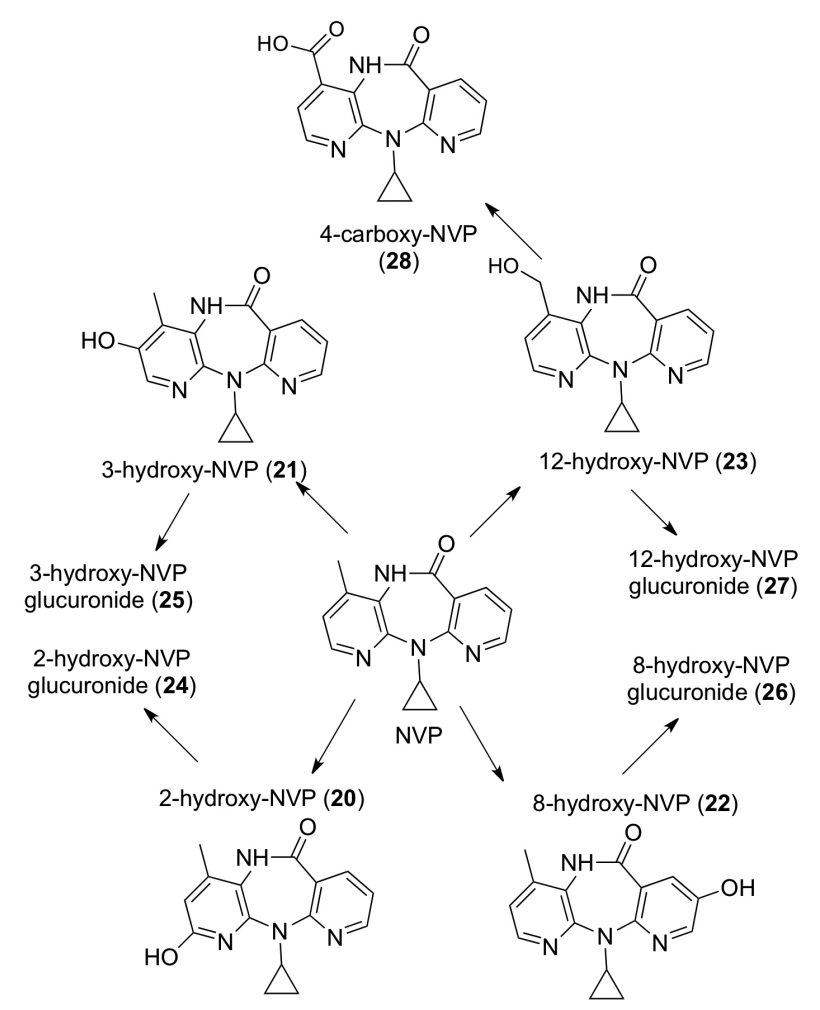

FIGURE 11 - Main metabolic routes of nevirapine.

6'-O-glucuronide conjugate (32). The cleavage of pyrimidinic ring of 6'-hydroxy-delavirdine was also observed, resulting in depyridinyl delavirdine, and cleavage of the amide bond forming indole carboxylic acid (33) and $\mathrm{N}$ isopropylpyridinepiperazine (34). Moreover, 6'-hydroxy delavirdine is sulfated (35) in rats, depyridinyl delavirdine is conjugated in rats and mice, and desalkyl delavirdine is hydroxylated at positions C-4' (36) and C-6' (37) of the pyrimidinic ring in rats and monkeys, with subsequent sulfation (38 and 39).

In mice, $N$-desalkylation of $N$-isopropylpyridinepiperazine produces $N$-deisopropylpyridinepiperazine, while the indole carboxylic acid undergoes conjugation. In monkeys, three additional metabolites were observed, identified as conjugation of desalkyl delavirdine with $\mathrm{N}$ acetylglucosamine, hydroxylation of delavirdine at the C-4 position of the indole ring to form 4-hydroxy delavirdine, followed by glucuronidation of 4-O-glucuronide, and $\mathrm{N}$-glucuronidation of the indole ring of delavirdine. The $\mathrm{N}$-desalkylation was the major metabolic fate in rats and monkeys, while in mice it was the cleavage of the amide bond (Chang et al., 1997a, b, c).

Experiments with human liver microsomes showed that delavirdine is an inhibitor of the isoforms CYP2C9, CYP2C19, CYP2D6 and CYP3A4, and that the $N$-desalkylation reaction is mediated by CYP2D6 and CYP3A4, while hydroxylation at position C-6' of pyrimi-

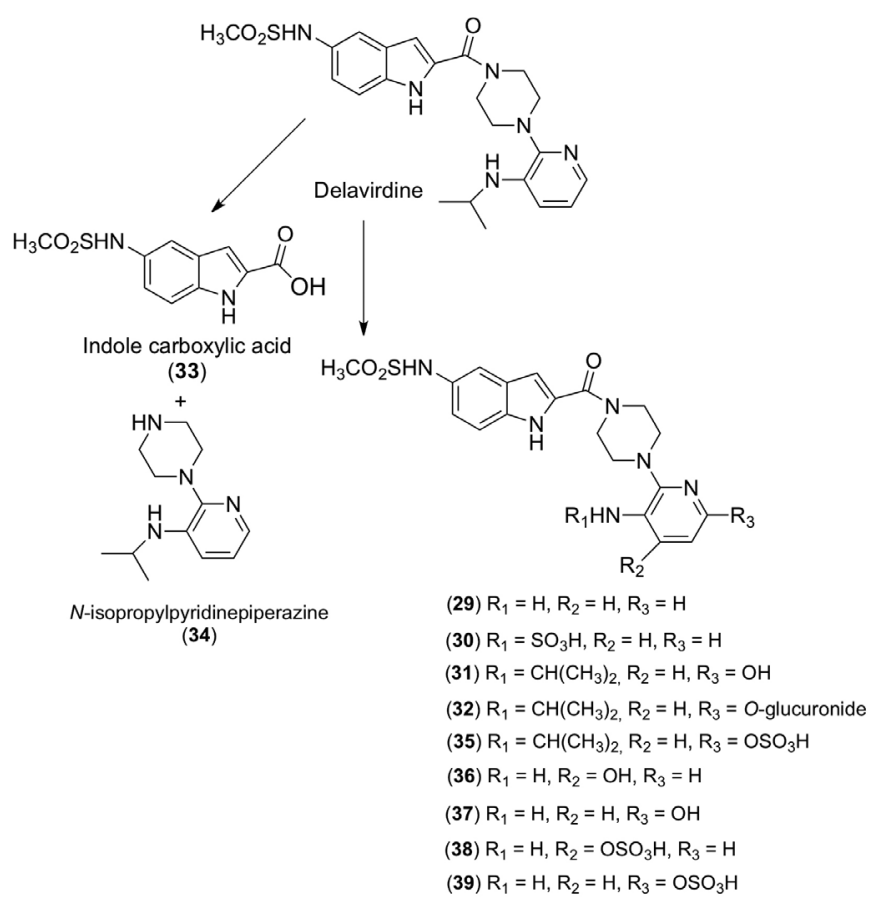

FIGURE 12 - Main metabolic routes of delavirdine.

dinic ring is catalyzed mainly by CYP3A4 (Voorman et al., 1998a, b; Voorman et al., 2001).

Efavirenz (EFV) (Figure 13) is extensively metabolized and small or insignificant amounts of the unchanged drug were found in urine of several species, including humans (Mutlib et al., 1999). The major metabolite isolated is the $O$-glucuronide (40) conjugate of the metabolite 8-hydroxy-efavirenz (41). EFV also undergoes glucuronidation to form the $\mathrm{N}$-glucuronide conjugate (42). The sulfation of 8-hydroxy-efavirenz (43) occurs in all species, except humans, while EFV hydroxylation to form 7-hydroxy-efavirenz (44), with subsequent glucuronidation (45) or sulfation (46), is not only observed in rats. Other reactions include the hydroxylation of the cyclopropane ring (C-14) of 8-hydroxy-efavirenz, producing 8,14-dihydroxy-efavirenz (47), and hydroxylation of its sulfated conjugate (48), which can also be formed from the sulfation of 47 , followed by glucuronidation (49) or conjugation with glutathione (GSH), with subsequent degradation, forming the adducts cysteinylglicine and cysteine. The hydroxylation of $\mathbf{4 4}$ is also observed, followed by glucuronidation (50) or sulfation (51) in position C-7 whereas 57 can still undergo glucuronidation (52) in position C-8 (Mutlib et al., 1999).

In vitro experiments using human liver microsomes have shown that 8-hydroxy-efavirenz was obtained as the major metabolite, as well as during in in vivo studies, while the metabolites 8,14-dihydroxy-efavirenz and 7-hydroxyefavirenz were also isolated. It was further demonstrated 
that CYP2B6 is the major isoform responsible for the production of 8-hydroxy-efavirenz and 8,14-dihydroxyefavirenz, and that other isoforms (CYPs 1A2, 3A4 and 3A5) seem to participate in a minority of this process (Ward et al., 2003). Rodriguez-Novoa and co-workers (2005) reported that CYP2B6 genetic polymorphisms contribute to variations in plasma concentration of EFV, proving the involvement of this isoform in its metabolism. In addition to being metabolized by CYP2B6, efavirenz is also its inhibitor, as well as its major metabolite, 8-hydroxy-efavirenz (Bumpus et al., 2006), which is also an inducer of the isoform CYP3A4 (Mouly et al., 2002).

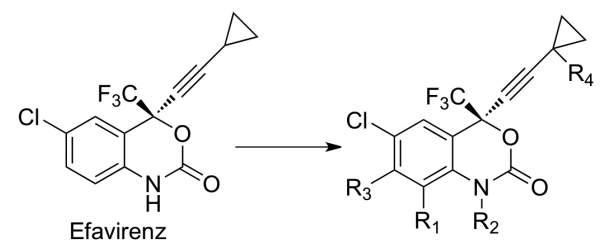
(40) $\mathrm{R}_{1}=$ O-glucuronide, $\mathrm{R}_{2}=\mathrm{H}, \mathrm{R}_{3}=\mathrm{H}, \mathrm{R}_{4}=\mathrm{H}$
(41) $\mathrm{R}_{1}=\mathrm{OH}, \mathrm{R}_{2}=\mathrm{H}, \mathrm{R}_{3}=\mathrm{H}, \mathrm{R}_{4}=\mathrm{H}$
(42) $R_{1}=H, R_{2}=$ glucuronide, $R_{3}=H, R_{4}=H$
(43) $\mathrm{R}_{1}=\mathrm{OSO}_{3} \mathrm{H}, \mathrm{R}_{2}=\mathrm{H}, \mathrm{R}_{3}=\mathrm{H}, \mathrm{R}_{4}=\mathrm{H}$
(44) $\mathrm{R}_{1}=\mathrm{H}, \mathrm{R}_{2}=\mathrm{H}, \mathrm{R}_{3}=\mathrm{OH}, \mathrm{R}_{4}=\mathrm{H}$
(45) $\mathrm{R}_{1}=\mathrm{H}, \mathrm{R}_{2}=\mathrm{H}, \mathrm{R}_{3}=$ O-glucuronide, $\mathrm{R}_{4}=\mathrm{H}$
(46) $\mathrm{R}_{1}=\mathrm{H}, \mathrm{R}_{2}=\mathrm{H}, \mathrm{R}_{3}=\mathrm{OSO}_{3} \mathrm{H}, \mathrm{R}_{4}=\mathrm{H}$
(47) $\mathrm{R}_{1}=\mathrm{OH}, \mathrm{R}_{2}=\mathrm{H}, \mathrm{R}_{3}=\mathrm{H}, \mathrm{R}_{4}=\mathrm{OH}$
(48) $\mathrm{R}_{1}=\mathrm{OSO}_{3} \mathrm{H}, \mathrm{R}_{2}=\mathrm{H}, \mathrm{R}_{3}=\mathrm{H}, \mathrm{R}_{4}=\mathrm{OH}$
(49) $\mathrm{R}_{1}=\mathrm{OSO}_{3} \mathrm{H}, \mathrm{R}_{2}=\mathrm{H}, \mathrm{R}_{3}=\mathrm{H}, \mathrm{R}_{4}=\mathrm{O}$-glucuronide
(50) $\mathrm{R}_{1}=\mathrm{H}, \mathrm{R}_{2}=\mathrm{H}, \mathrm{R}_{3}=\mathrm{O}$-glucuronide, $\mathrm{R}_{4}=\mathrm{OH}$
(51) $\mathrm{R}_{1}=\mathrm{OH}, \mathrm{R}_{2}=\mathrm{H}, \mathrm{R}_{3}=\mathrm{OSO}_{3} \mathrm{H}, \mathrm{R}_{4}=\mathrm{OH}$
(52) $\mathrm{R}_{1}=$ O-glucuronide, $\mathrm{R}_{2}=\mathrm{H}, \mathrm{R}_{3}=\mathrm{H}, \mathrm{R}_{4}=\mathrm{OH}$

FIGURE 13 - Main metabolites of efavirenz.

\section{Protease Inhibitors (PIs)}

At present, there are ten protease inhibitors (PIs) licensed for clinical use in the treatment of HIV infections. With the exception of tipranavir (which is based on a coumarine scaffold), all these PIs are based on the "peptidomimetic" principle, that is they contain an hydroxyethylene scaffold which mimics the normal peptide linkage (cleaved by the HIV protease) but which can itself not be cleaved. They thus prevent the HIV protease from carrying out its normal function, which is the proteolytic processing of precursor viral proteins into mature viral proteins. The ten PIs presently available for the treatment of HIV infections are saquinavir, ritonavir, indinavir, nelfinavir, amprenavir, lopinavir, atazanavir, fosamprenavir, tipranavir and darunavir (Madruga et al., 2007; Lazzarin et al., 2007).

Akin to NNRTIs, PIs are usually metabolized by oxidation mediated by CYP450. Saquinavir (SQV) (Fi- gure 14) has low oral bioavailability due to its extensive first-pass metabolism, which occurs mainly by CYP3A4 in small intestine, but also in liver, producing the same metabolites mono- and dihydroxy. In incubations of saquinavir with human small intestine and liver microsomes, two major metabolites (53 and $\mathbf{5 4}$ ) were isolated, produced from mono-hydroxylations of octahydro-2-( $1 H)$-isoquinolynil and (1,1-dimethylethyl)amino, respectively. Another five minority metabolites were found (Flitzsimmons, Collins, 1997). One of the major metabolites was subsequently identified as 6-equatorial-hydroxy-saquinavir (Eaglings et al., 2002).

Biotransformation of indinavir (IDV) (Figure 14) takes place primarily in liver by CYP3A4 (Chiba et al., 1996; Lin et al., 1996), and can also occur in the small intestine. Oxidative metabolites were found in both in vivo and in vitro experiments using liver and intestinal microsomes of humans and rats (Chiba, Hensleigh, Lin, 1997). In a study with healthy volunteers, seven major metabolites were found in urine, whose metabolic pathways were identified as: nitrogen pyridine glucuronidation (55); $\mathrm{N}$-oxidation of pyridine (56); $p$-hydroxylation of the phenylmethyl radical (57); 3'-hydroxylation of indan (58 and 59); and $N$-depyrido methylation (Balani et al., 1995). In experiments with liver microsomes, the production of the metabolite cis-(indan) hydroxylated by isoforms of the CYP2D subfamily was observed in Rhesus and Cynomolgus monkeys, while trans-(indan) hydroxylation and $N$-desalkylation were also observed in chimpanzees and humans, mediated by CYP3A4. The extent of metabolism in humans was the lowest among the four species studied (Chiba et al., 2000).

Anari and co-workers (2004) described the metabolic profile of indinavir, combining data obtained after analysis of human liver post-mitochondrial preparations in liquid chromatography coupled to mass spectroscopy (LC-MS/MS), and metabolic predictions generated by research based on structural similarity using the MDL Metabolite Database software. Two desalkylated, eleven monoxydated, three deoxygenated and two desalkylated/ monoxydated metabolites were identified, and the major derivatives resulted from the oxidation of pyridine, indanyl and fenylmethyl groups, and from $N$-desalkylation of piperazinil (Anari et al., 2004). Similar metabolites were found previously in another experiment employing LC-MS/MS analysis of the metabolites obtained from in vitro study (Yu, Cui, Davis, 1999).

Ritonavir (Figure 14) is extensively metabolized by rat, dog and human livers, through a variety of oxidative pathways and conjugation with glucuronic acid (60). The latter was only observed in dogs. The major metabolites identified in urine and feces of these three species were 


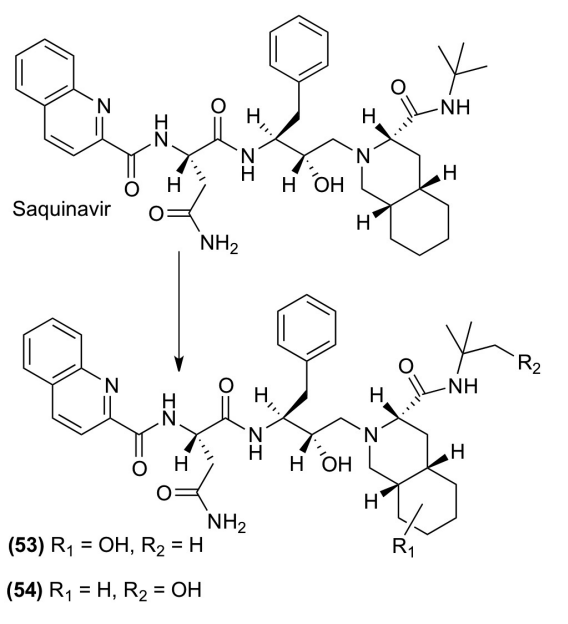

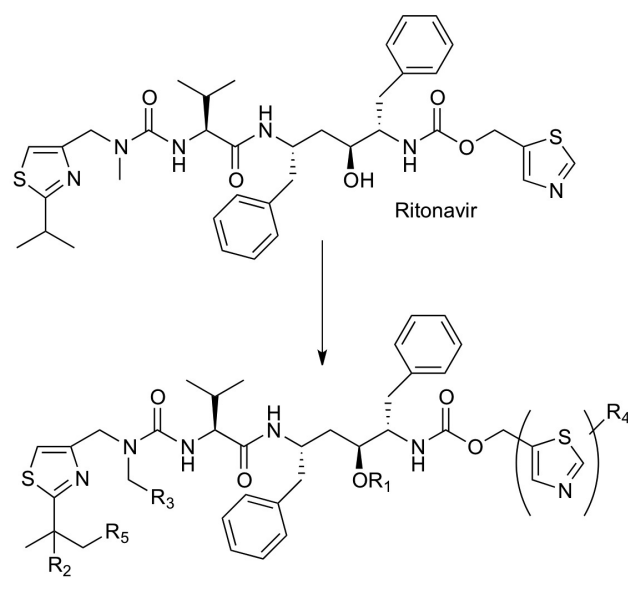

(60) $R_{1}=$ O-glucuronide, $R_{2}=H, R_{3}=H, R_{4}=H, R_{5}=H$

$R_{4}(61) R_{1}=H, R_{2}=O H, R_{3}=H, R_{4}=H, R_{5}=H$

(62) $R_{1}=H, R_{2}=H, R_{3}=O H, R_{4}=H, R_{5}=H$

(63) $\mathrm{R}_{1}=\mathrm{H}, \mathrm{R}_{2}=\mathrm{H}, \mathrm{R}_{3}=\mathrm{H}, \mathrm{R}_{4}=\mathrm{O}, \mathrm{R}_{5}=\mathrm{H}$

(64) $\mathrm{R}_{1}=\mathrm{H}, \mathrm{R}_{2}=\mathrm{OH}, \mathrm{R}_{3}=\mathrm{H}, \mathrm{R}_{4}=\mathrm{H}, \mathrm{R}_{5}=\mathrm{OH}$

(65) $R_{1}=H, R_{2}=H, R_{3}=$ O-glucuronide, $R_{4}=H, R_{5}=H$

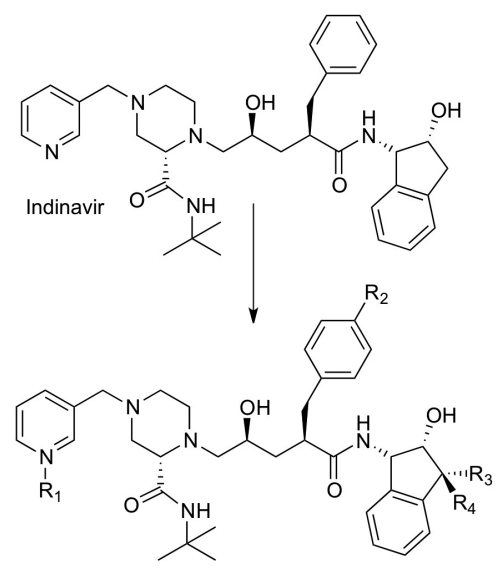

(55) $\mathrm{R}_{1}=\mathrm{N}$-glucuronide, $\mathrm{R}_{2}=\mathrm{H}, \mathrm{R}_{3}=\mathrm{H}, \mathrm{R}_{4}=\mathrm{H}$

(56) $\mathrm{R}_{1}=\mathrm{N}$-oxidation, $\mathrm{R}_{2}=\mathrm{H}, \mathrm{R}_{3}=\mathrm{H}, \mathrm{R}_{4}=\mathrm{H}$

(57) $\mathrm{R}_{1}=\mathrm{H}, \mathrm{R}_{2}=\mathrm{OH}, \mathrm{R}_{3}=\mathrm{H}, \mathrm{R}_{4}=\mathrm{H}$

(58) $\mathrm{R}_{1}=\mathrm{H}, \mathrm{R}_{2}=\mathrm{H}, \mathrm{R}_{3}=\mathrm{OH}, \mathrm{R}_{4}=\mathrm{H}$

(59) $\mathrm{R}_{1}=\mathrm{H}, \mathrm{R}_{2}=\mathrm{H}, \mathrm{R}_{3}=\mathrm{H}, \mathrm{R}_{4}=\mathrm{OH}$

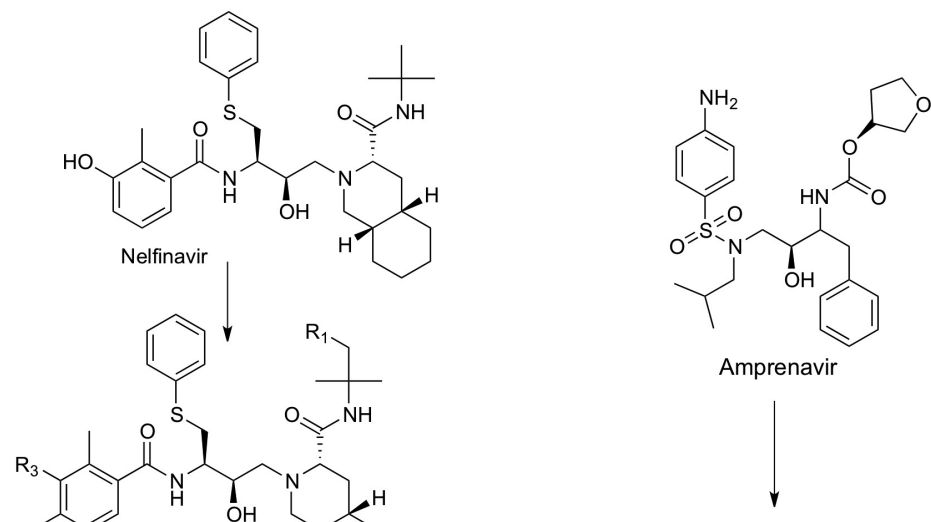

(69) Oxidation of THF ring (70) $N$-Dealkylation

(71) Oxidation of the aliphatic ring (72) Dehydration on the THF ring (73) Monoxidation of the aniline ring

FIGURE 14 - Main metabolites of protease inhibitors, saquinavir, indinavir, ritonavir, nelfinavir and amprenavir.

produced by loss of the thiazolyl carbamate, oxidation and loss of isopropyl-thiazolyl (61). Moreover, there was formation of $N$-hydroxymethyl urea (62), oxidation of the thiazolyl heteroatom (63) and a second oxidation of isopropyl of $\mathbf{6 1}(\mathbf{6 4})$, in rats only, as well as oxidation of the methyl thiazolyl from the metabolite that lost the carbamate thiazolyl, in dogs, loss of formaldehyde from $\mathbf{6 2}$ in rats and dogs, producing $N$-demethyl urea followed by oxidation to produce $N$-hydroxy urea. Glucuronidation of 62 was also observed in dogs (65). In vitro experiments demonstrated that the metabolite $\mathbf{6 1}$ and the metabolite that lost the isopropyl-thiazolyl group have antiretroviral activity (Denissen et al., 1997). A study using human liver microsomes showed that the production of $\mathbf{6 1}$ is mediated by enzymes of the CYP3A subfamily and by the isoform CYP2D6 (Kumar et al., 1996). In addition to being metabolized by CYP3A, ritonavir is also a potent inhibitor of this subfamily (Kumar et al., 1999).
Nelfinavir (NFV) (Figure 14) is biotransformed in the liver into three major metabolites, identified as nelfinavir-hydroxy-t-butyl-amide (66), 3,4-dihydroxy-nelfinavir (67) and 3-methoxy-4-hydroxy-nelfinavir (68) (Zhang et al., 1998). Compound 66 shows antiretroviral activity in vitro comparable to that of NFV, contributing to its oral activity in anti-HIV therapy, while $\mathbf{6 8}$ showed low activity (Zhang et al., 2001; Hirani, Raucy, Lasker, 2004). It has been shown that CYP3A4 is involved in the formation of metabolites 67 and 68, while 66 is produced by CYP2C19 (Wu et al., 1998; Lillibridge et al., 1998; Khaliq et al., 2000). 66 can also be metabolized by CYP3A4. Nelfinavir is also an inhibitor of CYP3A4 (Lillibridge et al., 1998) and CYP2B6 (Hesse et al., 2001) isoforms.

Amprenavir (Figure 14) is primarily oxidized in the liver by enzymes CYP450 (Decker et al., 1998). Experiments with human liver microsomes showed the production of five metabolites, the majority obtained by 
oxidation of the tetrahydrofuran ring (THF) (69). The others were formed by $\mathrm{N}$-desalkylation (70), oxidation of the aliphatic chain (71), dehydration of the THF ring (72) and mono-oxidation of the aniline ring (73). Enzymes of CYP3A subfamily appear to be involved in the formation of 69,71 and 73, while CYP2C9 contributes to the achievement of 71. It was also observed that the metabolism of amprenavir is reduced in neonates due to non-maturation of CYPs 3A4 and 3A5 (Tréluyer et al., 2003).

\section{Fusion Inhibitors (Fls)}

Enfuvirtide is the only fusion inhibitor (FI) approved (March 2003) by the US FDA, and to be licensed for the treatment of HIV-1 infection in the US, Australia and Europe (Fletcher, 2003). This compound is a synthetic polypeptide of 36 amino acids that is homologous to, and engages in a coil-coil interaction, with the heptad repeat (HR) regions of the viral glycoprotein gp41 (Matthews et al., 2004). As a consequence of this interaction, the fusion of the virus particle with the outer cell membrane is blocked. The FI enfuvirtide is the only anti-HIV compound that has a polymeric (i.e. polypeptidic) structure (structure not disclosed), and hence, is not orally bioavailable: it has to be injected parenterally (subcutaneously) twice daily. This makes the long-term use of enfuvirtide cumbersome and problematic. Enfuvirtide is primarily used in salvage therapy as part of drug combination regimens. Because enfuvirtide is a peptide, it is expected to undergo catabolism rather than metabolism by cytochrome $\mathrm{P} 450$ enzymes (Ferraiolo, Mohler, Gloff, 1992). Enfuvirtide did not inhibit the activities of CYP1A2, CYP2C19, CYP2D6, CYP2E1 or CYP3A4 in an open label, crossover trial in 12 HIV-infected adults (Hammer et al., 2006).

\section{Co-Receptor Inhibitors (CRIs)}

Co-receptor inhibitors (CRIs) interact with the coreceptor CCR5 or CXCR4 used by M (macrophage)-tropic and T (lymphocyte)-tropic HIV strains, respectively (now generally termed R5 and X4 strains, respectively), to enter the target cells. Within the whole virus-cell entry process, the interaction of the viral glycoprotein gp120 and the co-receptor falls between the interaction of the viral glycoprotein gp120 and the CD4 receptor, and the fusion of the viral glycoprotein gp41 with the outer cell membrane (Westby, van der Ryst, 2005). There is, at present, only one CRI available (licensed in 2007 for clinical use), namely, the CCR5 antagonist maraviroc (Perros, 2007). The major problem with CCR5 antagonists is that they are only active against R5 HIV strains, and that from a mixed population of X4/R5 HIV strains, they stimulate the selection of X4 strains. Ideally, a CCR5 antagonist should be combined with a CXCR4 antagonist so as to block both X4 and R5 HIV strains (Door et al., 2005).

Maraviroc is rapidly absorbed and extensively metabolized, although unchanged drug is the major circulating component in plasma and is the major excreted component after oral dosing. The metabolite profiling of plasma, urine and fecal samples showed that maraviroc is extensively metabolized with the major pathways involving oxidation and $N$-dealkylation reactions (Figure 15) (Walker et al., 2005; Abel et al., 2008). The most abundant metabolite detected in human plasma was a secondary amine product of $\mathrm{N}$-dealkylation (74, Figure 15). Moreover, Hyland and co-workers (2008) have demonstrated that maraviroc is predominantly metabolized by CYP3A4, and is not itself an inhibitor of CYP enzymes.

\section{Integrase Inhibitors (INIs)}

Although the integrase has been pursued for many years as a potential target for the development of new antiHIV compounds, the first integrase inhibitor (INI) licensed to treat HIV-1 infection, raltegravir, has only recently (in late 2007) been approved. The HIV integrase has essentially two important catalytic functions (3'-processing and strand transfer) (Chiu, Davies, 2004). Raltegravir (Figure 16) is targeted at the strand transfer reaction, as is elvitegravir (Figure 16), which is now entering phase III clinical trials. Elvitegravir is intended for once daily dosing (orally), while raltegravir has to be administered twice daily. It has proven highly effective in reducing viral loads in HIV-infected patients (Grinsztejn et al., 2007; Steigbigel et al., 2008; Cooper et al., 2008).

In preclinical studies, raltegravir was metabolized predominantly in the liver via the UDP-glucuronosyltransferase(UGT)-mediated pathway. In vivo and in vitro studies using isoform selective chemical inhibitors and cDNA-expressed UGTs showed that UGT1A1 is the primary enzyme responsible for the formation of raltegravir-glucuronide $(\mathbf{8 7})$ (Merck \& Co, 2007; Kassahun et al., 2007). In vitro studies demonstrate that raltegravir is not a substrate for cytochrome P450 (CYP) enzymes and does not inhibit CYP1A2, 2B6, 2C8, 2C9, 2C19, 2D6, or 3A or induce 3A4 (Iwamoto et al., 2008). Similarly, raltegravir is not an inhibitor of UGTs (UGT1A1 and UGT2B7) or P-glycoprotein (P-gp)mediated transport (Merck \& Co, 2007).

In clinical studies, metabolism via UGT1A1-mediated glucuronidation is the major pathway of elimination of raltegravir, with a minor component of elimination via kidney ( $\sim 9 \%$ of total dose excreted unchanged 


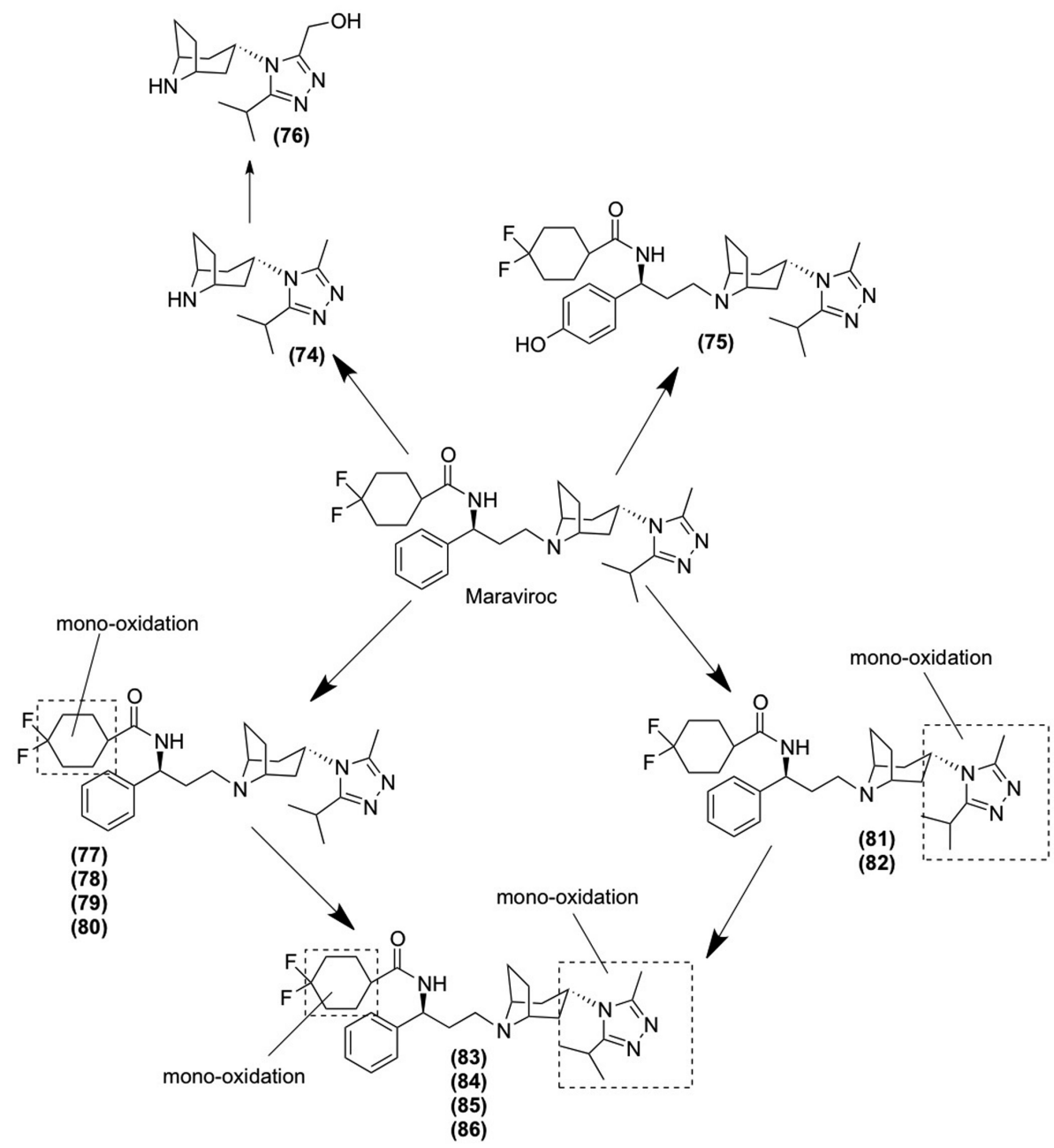

FIGURE 15 - Proposed metabolic pathways for maraviroc.

into urine). The only metabolite detected in humans was the phenolic hydroxyl glucuronide (87), and this metabolite does not have antiviral activity (Kassahun et al., 2007) (Figure 16). In a human ADME study, 51 and $32 \%$ of a radiolabeled raltegravir dose (parent and metabolite) was excreted in the feces and urine, respectively. The major circulating entity in plasma was the parent compound ( $69 \%$ of the total drug-related material in plasma), whereas most of the drug-related material in urine was accounted for by the glucuronide derivative ( $72 \%$ of the drug-related material in urine). In feces, only parent compound was detected, but it is likely that a good proportion of the raltegravir detected in feces is derived from hydrolysis of the glucuronide derivative secreted in bile as observed in preclinical species (Kassahun et al., 2007).

Elvitegravir undergoes metabolism primarily by CYP3A and also by glucuronidation via UGT1A1/3, which is the major pathway of elimination. Metabolites formed by these pathways are markedly less potent (5- to

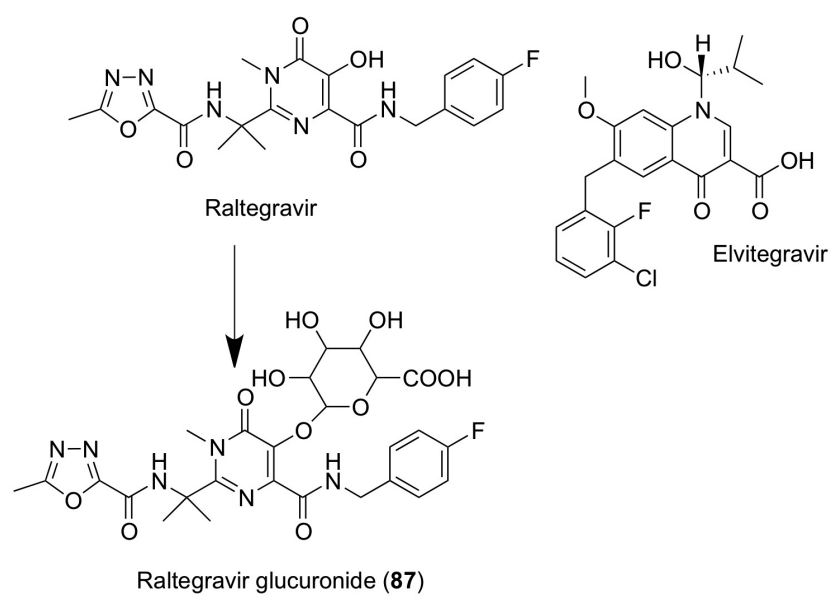

FIGURE 16 - Structures of raltegravir, its glucuronide metabolite and elvitegravir.

38 -fold) than the parent drug and are present in plasma at lower concentrations; thus, the metabolites do not contribute to the antiviral activity of elvitegravir (Ramanathan et al., 2007a). 
In a human ADME study with radiolabeled elvitegravir and boosting doses of ritonavir, $>90 \%$ of the circulating plasma was present as the parent compound. Radiolabeled compound was excreted primarily in the feces $(94.8 \%)$, with a minor amount in the urine $(6.7 \%)$. Fecal radioactivity consisted primarily of parent compound $(36 \%)$ and an oxidative metabolite $(46 \%)$. Urine contained low levels of various metabolites (Ramanathan et al., 2007b).

\section{FINAL CONSIDERATIONS}

Despite the significant advances made in understanding the mechanism of HIV infection and in identifying effective treatment approaches, the search for optimum treatment strategies for AIDS remains a major challenge.

This review has demonstrated that the cytochrome P450 family of enzymes is responsible for the metabolism of the majority of antiretroviral drugs, but for some of the nucleoside reverse transcriptase inhibitors (NRTIs), hepatic conjugation via UDP-glucuronosyltransferases as well as via alcohol dehydrogenase is important. NRTIs are the most studied class of anti-HIV agents in terms of metabolism. In contrast, limited published data are currently available on the other classes of anti-HIV agents and much of the available information is obtained from manufacturers and the clinical studies sponsored by the manufacturers. More systematic studies on metabolism, such as metabolite formation, the presence of active metabolites and mechanisms of chemical toxicity, are needed regarding antiretroviral therapy.

\section{ACKNOWLEDGEMENTS}

The authors gratefully acknowledge financial support from $\mathrm{CNPq}$ (The National Council for Scientific and Technological Development), CAPES (The Coordenação de Aperfeicoamento de Pessoal de Nível Superior) and FAPEG (The State of Goias Research Foundation), Brazil.

\section{REFERENCES}

ABEL, S.; RUSSELL, D.; WHITLOCK, L.A.; RIDGEWAY, C.E.; NEDDERMAN, A.N.R.; WALKER, D.K. Assessment of the absorption, metabolism, and absolute bioavailability of maraviroc in healthy male subjects. Br. J. Clin. Pharmacol., v.65, suppl.1, p.60-67, 2008.

ADAMSON, C.S.; FREED, E.O. Anti-HIV-1 Therapeutics: from FDA-approved drugs to hypothetical future targets. Mol. Interv., v.9, p.70-74, 2009.
AFZELIUS, L.; ARNBY, C.H.; BROO, A.; CARLSSON, L.; ISAKSSON, C.; ULRIK JURVA, U.; KJELLANDER, B.; KOLMODIN, K.; NILSSON, K.; RAUBACHER, F.; WEIDOLF , L. State of the art tools for computational site of metabolism predictions: comparative analysis, mechanistically insights, and future applications. Drug Metab. Rev., v.39, p.61-86, 2007.

ANARI, M.R.; SANCHEZ, R.I.; BAKHTIAR, R.; FRANKLIN, R.B.; BAILLIE, T.A. Integration of knowledge-based metabolic predictions with liquid chromatography datadependent tandem mass spectrometry for drug metabolism studies: application to studies on the biotransformation of indinavir. Anal. Chem., v.76, p.823-832, 2004.

ANINAT, C.; PITON, A.; GLAISE, D.; LE CHARPENTIER, T.; LANGOUET, S.; MOREL, F.; GUGUEN-GUILLOUZO, C.; GUILLOUZO, A. Expression of cytochromes p450, conjugating enzymes and nuclear receptors in human hepatoma heparg cells. Drug Metab. Dispos., v.34, p.7583, 2006 .

ASHA S.; VIDYAVATHI, M. Cunninghamella - A microbial model for drug metabolism studies -A review. Biotechnol. $A d v$., v.27, p.16-29, 2009.

AZERAD, R. Microbial models for drug metabolism. $A d v$. Biochem. Eng. Biotechnol., v.63, p.163-218, 1999.

BALANI, S.K.; ARISON, B.H.; MATHAI, L.; KAUFFMAN, L.R.; MILLER, R.R.; STEARNS, R.A.; CHEN, I.W.; LIN, J.H. Metabolites of L-735, 524, a potent HIV 1-protease inhibitor, in human urine. Drug Metab. Dispos., v.23, p.266-270, 1995.

BALZARINI, J.; HOLÝ, A.; JINDRICH, J.; NAESENS, L.; SNOECK, R.; SCHOLS, D.; DE CLERCQ, E. Differential antiherpesvirus and antiretrovirus effects of the (S) and (R) enantiomers of acyclic nucleoside phosphonates: potent and selective in vitro and in vivo antiretrovirus activities of (R)-9-(2-phosphonomethoxypropyl)- 2,6-diaminopurine. Antimicrob. Agents Chemother, v.37, p.332-338, 1993.

BALZARINI, J.; NAVE, J.F.; BECKER, M.A.; TATIBANA, M.; DE CLERQ, E. Kinetic properties of adenine nucleotide analogues against purified 5-phosphoribosyl-1pyrophosphate synthetases from E. coli, rat liver and human erythrocytes. Nucleos. Nucleot. Nucl., v.14, p.1861-1871, 1995. 
BARRÉ-SINOUSSI, F.; CHERMANN, J.C.; REY, F.; NUGEYRE, M.T.; CHAMARET, S.; GRUEST, J.; DAUGUET, C.; AXLER-BLIN, C.; VÉZINET-BRUN, F.; ROUZIOUX, C.; ROZENBAUM, W.; MONTAGNIER, L. Isolation of a T-lymphotropic retrovirus from a patient at risk for acquired immune deficiency syndrome (AIDS). Science, v.220, p.868-871, 1983.

BRAGA, R.C.; TORRES, A.C.B.; PERSIANO, C.B.; ALVES, R.O.; FRAGA, C.A.M.; BARREIRO, E.J.; DE OLIVEIRA, V. Determination of the cardioactive prototype LASSBio-294 and its metabolites in dog plasma by LC-MS/MS: Application for a pharmacokinetic study. J. Pharm. Biomed. Anal., in press, 2011, DOI: 10.1016/j. jpba.2011.02.031.

BRUZZESE, V.L.; GILLUM, J.G.; ISRAEL, D.S.; JOHNSON, G.L.; KAPLOWITZ, L. G.; POLK, R.E. Effect of fluconazole on pharmacokinetics of 2',3'-dideoxyinosine in persons seropositive for human immunodeficiency virus. Antimicrob. Agents Chemother., v.39, p.1050-1053, 1995.

BUMPUS, N.N.; KENT, U.M.; HOLLENBERG, P.F. Metabolism of efavirenz and 8-hydroxyefavirenz by $\mathrm{P} 450$ 2B6 leads to inactivation by two distinct mechanisms. $J$. Pharmacol. Exp. Ther, v.318, p.345-351, 2006.

CANAVAN, N. FDA and drug companies alike want ADME-tox testing performed earlier and earlier in a drug's life cycle. Drug Discov. Dev., v.10, p.34-36, 2007.

CARNEIRO, E.O.; MENEGATTI, R.; FRAGA, C.A.M.; BARREIRO, E.J.; DE OLIVEIRA, V. Microbial models of animal metabolism: application to a study of the metabolism of LASSBio-873. Braz. J. Pharm. Sci., v.41, p.392-392, 2005 .

CARNEIRO, E.O.; ANDRADE, C.H.; BRAGA, R.C.; TÔRRES, A.C.B., ALVES, R.O.; LIÃO, L.M.; FRAGA, C.A.M.; BARREIRO, E.J.; DE OLIVEIRA, V. Structurebased prediction and biosynthesis of the major mammalian metabolite of the cardioactive prototype LASSBio-294. Bioorg. Med. Chem. Lett., v.20, p.3734-3736, 2010.

CHANG, M.; SOOD, V.K.; KLOOSTERMAN, D.A.; HAUER, M.J.; FAGERNESS, P. E.; SANDERS, P.E.; VRBANAC, J.J. Identification of the metabolites of the HIV-1 reverse transcriptase inhibitor delavirdine in monkeys. Drug Metab. Dispos., v.25, p.814-827, 1997a.
CHANG, M.; SOOD, V.K.; WILSON, G.J.; KLOOSTERMAN, D.A.; SANDERS, P.E.; HAUER, M.J.; ZHANG, W.; BRANSTETTER, D.G. Metabolism of the HIV-1 Reverse transcriptase inhibitor delavirdine in mice. Drug Metab. Dispos., v.25, p.828-839, 1997 b.

CHANG, M.; SOOD, V.K.; WILSON, G.J.; KLOOSTERMAN, D.A.; SANDERS, P. E.; HAUER, M.J.; FAGERNESS, P.E. Metabolism of the human immunodeficiency virus type 1 reverse transcriptase inhibitor delavirdine in rats. Drug Metab. Dispos., v.25, p.228-242, 1997 c.

CHIBA, M.; HENSLEIGH, M.; LIN, J.H. Hepatic and intestinal metabolism of indinavir, an HIV protease inhibitor, in rat and human microsomes: Major role of CYP3A. Biochem. Pharmacol., v.53, p.1187-1195, 1997.

CHIBA, M.; HENSLEIGH, M.; NISHIME, J.A.; BALANI, S.K.; LIN, J.H. Role of cytochrome P450 3A4 in human metabolism of MK-639, a potent human immunodeficiency virus protease inhibitor. Drug Metab. Dispos., v.24, p.307314, 1996.

CHIBA, M.; NISHIME, J.A.; NEWAY, W.; LIN, Y.; LIN, J.H. Comparative in vitro metabolism of indinavir in primates - a unique stereoselective hydroxylation in monkey. Xenobiotica, v.30, p.117-129, 2000.

CHIU, T.K.; DAVIES, D.R. Structure and function of HIV-1 integrase. Curr.Top. Med. Chem., v.4, p.965-77, 2004.

COHEN M.S.; HELLMANN, N.; LEVY, J.A.; DECOCK, K.; LANGE, J. The spread, treatment, and prevention of HIV1: evolution of a global pandemic. J. Clin. Invest., v.118, p.1244-1254, 2008.

COLLINS, J.M. Inter-species differences in drug properties. Chem. Biol. Interact., v.134, p.237-242, 2001.

COOPER, D.A.; STEIGBIGEL, R.T.; GATELL, J.M.; ROCKSTROH, J.K.; KATLAMA, C.; YENI, P.; LAZZARIN, A.; CLOTET, B.; KUMAR, P.N.; ERON, J.E.; SCHECHTER, M.; MARKOWITZ, M.; LOUTFY, M.R.; LENNOX, J.L.; ZHAO, J.; CHEN, J.; RYAN, D.M.; RHODES, R.R.; KILLAR, J.A.; GILDE, L.R.; STROHMAIER, K.M.; MEIBOHM, A.R.; MILLER, M.D.; HAZUDA, D.J.; NESSLY, M.L.; DINUBILE, M.J.; ISAACS, R.D.; TEPPLER, H.; NGUYEN, B.Y. Subgroup and resistance analyses of raltegravir for resistant HIV-1 infection. N. Engl. J. Med., v.359, p.355-365, 2008. 
COSTA, E.M.M.B.; PIMENTA, F.C.; LUZ, W.C.; DE OLIVEIRA V. Selection of filamentous fungi of the Beauveria genus able to metabolize quercetin like mammalian cells. Braz. J. Microbiol., v.39, p.405-408, 2008.

COURT, M.H.; KRISHNASWAMY, S.; HAO, Q.; DUAN, S.X.; PATTEN, C.J.; VON MOLTKE, L.L.; GREENBLATT, D.J. Evaluation of 3_-azido-3_-deoxythymidine, morphine and codeine as probe substrates for UDP-glucuronosyltransferase 2B7 (UGT2B7) in human liver microsomes: specificity and influence of the UGT2B7*2 polymorphism. Drug Metab. Dispos., v.31, p.1125-1133, 2003.

CRETTON, E.M.; SCHINAZI, R.F.; MCCLURE, H.M.; ANDERSON, D.C.; SOMMADOSSI, J.P. Pharmacokinetics of 3'-azido-3'-deoxythymidine and its catabolites and interactions with probenecid in rhesus monkeys. Antimicrob. Agents Chemother., v.35, p.801-807, 1991.

CRETTON, E.M.; ZHOU, Z.; KIDD, L.B.; MCCLURE, H.M.; KAUL, S.; HITCHCOCK, M.J.; SOMMADOSSI, J.P. In vitro and in vivo disposition and metabolism of 3'-deoxy2',3'-didehydrothymidine. Antimicrob. Agents Chemother., v.37, p.1816-1825, 1993.

CRUCIANI, G.; CAROSATI, E.; DE BOECK, B.; ETHIRAJULU, K.; MACKIE, C.; HOWE, T.; VIANELLO, R. MetaSite: Understanding metabolism in human cytochromes from the perspective of the chemist. J. Med. Chem., v.48, p.6970-6979, 2005.

DARVAS F. Predicting metabolic pathways by logic programming. J. Mol. Graph., v.6, p.80-86, 1988.

DE CLERCQ, E. Anti-HIV drugs. Verh. K. Acad. Geneesk. Belg., v.64, p.81-104, 2007.

DE CLERCQ, E. Potential of acyclic nucleoside phosphonates in the treatment of DNA virus and retrovirus infections. Expert Rev. Anti-Infect. Ther., v.1, p.21-43, 2003.

DE GRAFF, C.; VERMEULEN, N.P.E.; FEENSTRA, K.A. Cytochrome P450 in silico: an integrative modeling approach. J. Med. Chem., v.48, p.2725-2755, 2005.

DECKER, C.J.; LAITINEN, L.M.; BRIDSON, G.W.; RAYBUCK, S.A.; TUNG, R.D.; CHATURVEDI, P.R. Metabolism of amprenavir in liver microsomes: role of CYP3A4 inhibition for drug interactions. J. Pharm. Sci., v.87, 803-807, 1998.
DENISSEN, J.F.; GRABOWSKI, B.A.; JOHNSON, M.K.; BUKO, A.M.; KEMPF, D. J.; THOMAS, S.B.; SURBER, B.W. Metabolism and disposition of the HIV-1 protease inhibitor ritonavir (ABT-538) in rats, dogs, and humans. Drug Metab. Dispos., v.25, p.489-501, 1997.

DIAS, L.E.S.; ANDRADE, C.H.; PAZINI, F.; DE OLIVEIRA, V. Preparation of new metabolites from lamivudine by filamentous fungi bioconversion. Braz. J. Pharm. Sci., v.41, p.133-133, 2005.

DORR, P.; WESTBY, M.; DOBBS, S.; GRIFFIN, P.; IRVINE, B.; MACARTNEY, M.; MORI, J.; RICKETT, G.; SMITH-BURCHNELL, C.; NAPIER, C.; WEBSTER, R.; ARMOUR, D.; PRICE, D.; STAMMEN, B.; WOOD, A.; PERROS, M. Maraviroc (UK-427 857), a potent, orally bioavailable, and selective small-molecule inhibitor of chemokine receptor CCR5 with broad-spectrum anti-human immunodeficiency virus type 1 activity. Antimicrob. Agents Chemother., v.49, p.4721-4732, 2005.

EAGLINGS, V.A.; WILTSHIRE, H.; WHITCOMBE, I.W.A.; BACK, D.J. CYP3A4-mediated hepatic metabolism of the $\mathrm{HIV}-1$ protease inhibitor saquinavir in vitro. Xenobiotica, v.32, p.1-17, 2002.

EKINS, S.; ANDREYEV, S.; RYABOV, A.; KIRILLOV, E.; RAKHMATULIN, E.A.; SOROKINA, S.; BUGRIM, A.; NIKOLSKAYA, T. A combined approach to drug metabolism and toxicity assessment. Drug Metab. Dispos., v.34, p.495-503, 2006.

ERICKSON, D.A.; MATHER, G.; TRAGER, W.F.; LEVY, R.H.; KEIRNS, J.J. Characterization of the in vitro biotransformation of the HIV-1 reverse transcriptase inhibitor nevirapine by human hepatic cytochromes P-450. Drug Metab. Dispos., v.27, p.1488-1495, 1999.

FALETTO, M.B.; MILLER, W.H.; GARVEY, E.P.; ST. CLAIRE, M.H.; DALUGE, S. M.; GOOD, S.S. Unique intracellular activation of the potent anti-human immunodeficiency virus agent 1592U89. Antimicrob. Agents Chemother., v.41, p.1099-1107, 1997.

FAUCI, A.S. HIV and AIDS: 20 years of science. Nat. Med., v.9, p.839-843, 2003.

FERRAIOLO, B.L.; MOHLER, M.A.; GLOFF, C.A. Goals and analytical methodologies for protein disposition studies. In:__Protein pharmacokinetics and metabolism. New York: Plenum Press. 1992. p.1-21. 
FITZSIMMONS, M.E.; COLLINS, J.M. Selective biotransformation of the human immunodeficiency virus protease inhibitor saquinavir by human small intestinal cytochrome P450 3A4: Potential contribution to high first-pass metabolism. Drug Metab. Dispos., v.25, p.256-266, 1997.

FLETCHER, C.V. Enfuvirtide, a new drug for HIV infection. Lancet, v.361, p.1577-78, 2003.

FREITAS, L.M. Avaliação do perfil metabólico da estavudina através do emprego da bioconversão e da modelagem molecular do citocromo P-450 CYP3A4. Goiânia, 2009. 173 p. [Dissertação de Mestrado. Faculdade de Farmácia. Universidade Federal de Goiás].

FURMAN, P.A.; FYFE, J.A.; ST. CLAIR, M.H.; WEINHOLD, K.; RIDEOUT, J.L.; FREEMAN, G.A.; NUSINOFFLEHRMAN, S.; BOLOGNESI, D.P.; BRODER, S.; MITSUYA, H.; BARRY, D.W. Phosphorylation of 3'-azido-3'-deoxythymidine and selective interaction of the 5'-triphosphate with human immunodeficiency virus reverse transcriptase. Proc. Natl. Acad. Sci. USA, v.83, p.8333-8337, 1986.

GOMES, T.C.F.; ANDRADE, C.H.; CIRILO, H.N.C.; RIOS, D.P.; DIAS, L.E.S.; PAZINI, F.; DE OLIVEIRA, V. Bioconversão de antiretrovirais por Cunninghamella echinulata ATCC 9244. In: ENCUENTRO REGIONAL BIOCATÁLISIS Y BIOTRANSFORMACIONES, 2., 2006, São Paulo. Resumos. São Paulo: Instituto de Química da Universidade de São Paulo, 2006. p.51-51.

GOMEZ-LECHON, M.J.; DONATO, M.T.; CASTELL, J.V.; JOVER, R. Human hepatocytes in primary culture: the choice to investigate drug metabolism in man. Curr. Drug Metab., v.5, p.443-462, 2004.

GOOD, S.S.; DALUGE, S.M.; CHING, S.V.; AYERS, M.M.; MAHONY, W.B.; FALETTO, M.B.; DOMIN, B.A.; OWENS, B.S.; DORNSIFE, R.E., MCDOWELL, J.A.; LAFON, S.W.; SYMONDS, W.T. 1592 U89 succinate-preclinical toxicological and disposition studies and preliminary clinical pharmacokinetics. Antiviral Res., v.26, p.A229, 1995.

GRINSZTEJN, B.; NGUYEN, B.Y.; KATLAMA, C.; GATELL, J.M.; LAZZARIN, A.; VITTECOQ, D.; GONZALEZ, C.J.; CHEN, J.; HARVEY, C.M.; ISAACS, R.D. Safety and efficacy of the HIV-1 integrase inhibitor raltegravir (MK0518) in treatment-experienced patients with multidrugresistant virus: a phase II randomised controlled trial. Lancet, v.369, p.1261-1269, 2007.
GUENGERICH, F.P. Cytochrome P450s and other enzymes in drug metabolism and toxicity. AAPS Journal, v.8, p.E101$111,2006$.

HAMMER, S.M.; SAAG, M.S.; SCHECHTER, M.; MONTANER, J.S.; SCHOOLEY, R.T.; JACOBSEN, D.M.; THOMPSON, M.A.; CARPENTER, C.C.; FISCHL, M.A.; GAZZARD, B.G.; GATELL, J.M.; HIRSCH, M.S.; KATZENSTEIN, D.A.; RICHMAN, D.D.; VELLA, S.; YENI, P.G.; VOLBERDING, P.A. Treatment for adult HIV infection: 2006 recommendations of the International AIDS Society--USA panel. JAMA, v.296, p.827-843, 2006.

HESSE, L.M.; VON MOLTKE, L.L.; SHADER, R.I.; GREENBLATT, D.J. Ritonavir, efavirenz, and nelfinavir inhibit CYP2B6 activity in vitro: potential drug interactions with bupropion. Drug Metab. Dispos., v.29, p.100-102, 2001.

HIRANI, V N.; RAUCY, J.L.; LASKER, J.M. Conversion of the HIV protease inhibitor nelfinavir to a bioactive metabolite by human liver CYP2C19. Drug Metab. Dispos., v.32, p.1462-1467, 2004.

HORWITZ, J.P.; CHUA, J.; NOEL, M. Nucleosides V. Monomethanesulfonates of 1-(2-deoxy-b-D-threopentofuranosyl)thymine. J. Org. Chem., v.29, 2076-2078, 1964.

HYLAND, R.; DICKINS, M.; COLLINS, C.; JONES H.; JONES, B. Maraviroc: in vitro assessment of drug-drug interaction potential. Br. J. Clin. Pharmacol., v.66, suppl.4, p.498-507, 2008.

IWAMOTO, M.; KASSAHUN, K.; TROYER, M.D.; HANLEY, W.D.; LU, P.; RHOTON, A.; PETRY, A.S.; GHOSH, K.; MANGIN, E.; DENOIA, E.P.; WENNING, L.A.; STONE, J.A.; GOTTESDIENER, K.M.; WAGNER, J.A. Lack of a pharmacokinetic effect of raltegravir on midazolam: in vitro/ in vivo correlation. J. Clin. Pharmacol., v.48, p.209-214, 2008.

JOHNSON, M.A.; HORAK, J.; BREUEL, P. The pharmacokinetics of iamivudine in patients with impaired hepatic function. Eur. J. Clin. Pharmacol., v.54, p.363-366, 1998.

KASSAHUN, K.; MCINTOSH, I.; CUI, D.; HRENIUK. D.; MERSCHMAN, S.; LASSETER, K.; AZROLAN, N.; IWAMOTO, M.; WAGNER J.A.; WENNING, L.A. Metabolism and disposition in humans of raltegravir (MK-0518), an anti-AIDS drug targeting the human immunodeficiency virus 1 integrase enzyme. Drug Metab. Dispos., v.35, p.1657-1663, 2007. 
KAUL, S.; SHYU, W.C.; SHUKLA, U.A.; DANDEKAR, K.A.; BARBHAIYA, R.H. Absorption, disposition, and metabolism of [14C]didanosine in the beagle dog. Drug Metab. Dispos., v.21, p.447-453, 1993.

KHALIQ, Y.; GALLICANO, K.; SEGUIN, I.; FYKE, K.; CARIGNAN, G.; BULMAN, D.; BADLEY, A.; CAMERON, D.W. Single and multiple dose pharmacokinetics of nelfinavir and CYP2C19 activity in human immunodeficiency virus-infected patients with chronic liver disease. Br. J. Clin. Pharmacol., v.50, p.108115,2000 .

KLOPMAN, G.; DIMAYUGA, M.; TALAFOUS, J. META A program for the evaluation of metabolic transformation of chemicals. J. Chem. Inf. Comput. Sci., v.34, p.1320-1325, 1994.

KRUSZEWSKA, H.; CHMIELOWIEC, U.; BEDNAREK, E.; WITOWSKA-JAROSZ, J.; DOBROWOLSKI, J.C.; MISICKA, A. Spectroscopic identification of AZT derivative obtained from biotransformation of AZT by Stenotrophomonas maltophilia. J. Mol. Struct., v.651-653, p.645-650, 2003.

KUMAR, G.N.; DYKSTRA, J.; ROBERTS, E.M.; JAYANTI, V.K.; HICKMAN, D.; UCHIC, J.; YAO, Y.; SURBER, B.; THOMAS, S.; GRANNEMAN, G.R. Potent Inhibition of the cytochrome P-450 3A-mediated human liver microsomal metabolism of a novel HIV protease inhibitor by ritonavir: a positive drug-drug interaction. Drug Metab. Dispos., v.27, p.902-908, 1999.

KUMAR, G.N.; RODRIGUES, A.D.; BUKO, A.M.; DENISSEN, J.F. Cytochrome P450-mediated metabolism of the HIV-1 protease inhibitor ritonavir (ABT-538) in human liver microsomes. J. Pharmacol. Exp. Ther., v.277, p.423-431, 1996.

KUMAR, G.N.; SURAPANENI, S. Role of drug metabolism in drug discovery and development. Med. Res. Rev., v.21, p.397-411, 2001.

LAZZARIN, A.; CAMPBELL, T.; CLOTET, B.; JOHNSON, M.; KATLAMA, C.; MOLL, A.; TOWNER, W.; TROTTIER, B.; PEETERS, M.; VINGERHOETS, J.; DE SMEDT, G.; BAETEN, B.; BEETS, G.; SINHA, R.; WOODFALL, B. Efficacy and safety of TMC125 (etravirine) in treatmentexperienced HIV-1-infected patients in DUET-2: 24-week results from a randomised, double-blind, placebo-controlled trial. Lancet, v.370, p.39-48, 2007.
LE VEE, M.; JIGOREL, E.; GLAISE, D.; GRIPON, P.; GUGUEN-GUILLOUZO, C.; FARDEL, O. Functional expression of sinusoidal and canalicular hepatic drug transporters in the differentiated human hepatoma HepaRG cell line. Eur. J. Pharm. Sci., v.28, p.109-117, 2006.

LEE, J.S.; OBACH, R.S.; FISHER, M.B. Drug metabolizing enzymes. Cytochrome P450 and other enzymes in drug discovery and development. New York: Marcel Dekker, Inc., 2003. $587 \mathrm{p}$.

LI, A.P.; MAUREL, P.; GOMEZ-LECHON, M.J.; CHENG, L.C.; JURIMA-ROMET, M. Preclinical evaluation of drug-drug interaction potential: present status of the application of primary human hepatocytes in the evaluation of cytochrome P450 induction. Chem. Biol. Interact., v.107, p.5-16, 1997.

LI, X.; CHAN, W.K. Transport, metabolism and elimination mechanisms of anti-HIV agents. Adv. Drug Delivery Rev., v.39, p.81-103, 1999.

LILLIBRIDGE, J.H.; LIANG, B.H.; KERR, B.M.; WEBBER, S.; QUART, B.; SHETTY, B.V.; LEE, C.A. Characterization of the selectivity and mechanism of human cytochrome P450 Inhibition by the human immunodeficiency virus-protease inhibitor nelfinavir mesylate. Drug Metab. Dispos., v.26, p.609-616, 1998.

LIN, J.H.; CHIBA, M.; BALANI, S.K.; CHEN, I. W.; KWEI, G.Y.; VASTAG, K.J.; NISHIME, J.A. Species differences in the pharmacokinetics and metabolism of indinavir, a potent HIV protease inhibitor. Drug Metab. Dispos., v.24, p.1111$1120,1996$.

MACKENZIE, P.I.; OWENS, I.S.; BURCHELL, B.; BOCK, K.W.; BAIROCH, A.; BÉLANGER, A.; FOURNELGIGLEUX, S.; GREEN, M.; HUM, D.W.; IYANAGI, T.; LANCET, D.; LOUISOT, P.; MAGDALOU, J.; CHOWDHURY, J.R.; RITTER, J.K.; SCHACHTER, H.; TEPHLY, T.R.; TIPTON, K.F.; NEBERT, D.W. The UDP glycosyltransferase gene superfamily: recommended nomenclature update based on evolutionary divergence. Pharmacogenet., v.7, p.255-269, 1997.

MADRUGA, J.V.; CAHN, P.; GRINSZTEJN, B.; HAUBRICH, R.; LALEZARI, J.; MILLS, A.; PIALOUX, G.; WILKIN, T.; PEETERS, M.; VINGERHOETS, J.; DE SMEDT, G.; LEOPOLD, L.; TREFIGLIO, R.; WOODFALL, B. Efficacy and safety of TMC125 (etravirine) in treatment-experienced HIV-1-infected patients in DUET-1: 24-week results from a randomised, double-blind, placebo-controlled trial. Lancet, v.370, p.29-38, 2007. 
MATTHEWS, T.; SALGO, M.; GREENBERG, M.; CHUNG, J.; DEMASI, R.; BOLOGNESI, D. Enfuvirtide: the first therapy to inhibit the entry of HIV-1 into host CD4 lymphocytes. Nat. Rev. Drug Discov., v.3, p.215-225, 2004.

MCDOWELL, J.A.; CHITTICK, G.E.; RAVITCH, J.R.; POLK, R.E.; KERKERING, T.M.; STEIN, D.S. Pharmacokinetics of [14C]Abacavir, a human immunodeficiency Virus Type 1 (HIV-1) reverse transcriptase inhibitor, administered in a single oral dose to HIV-1-infected adults: a mass balance study. Antimicrob. Agents Chemother, v.43, p.2855-2861, 1999.

MEHELLOU, W.; DE CLERCQ, E. Twenty-six years of antiHIV drug discovery: where do we stand and where do we go? J. Med. Chem., v.53, p.521-538, 2010.

MEIJER, D.K.F.; SWART, P.J. Isolated perfused liver as a tool to study the disposition of peptides, liver first-pass effects, and cell-specific drug delivery. J. Controlled Release, v.46, p.139-156, 1997.

MERCK \& CO., Inc. Raltegravir tablets FDA Advis. Comm. Meet. Briefing Document (Background Package), Whitehouse Station, NJ: Merck \& Co, Inc; 2007. p.19.

MERTA, A.; VOTRUBA, I.; JINDRICH, J.; HOLÝ, A.; CIHLÁR, T.; ROSENBERG, I.; OTMAR, M.; HERVE, T.Y. Phosphorylation of 9-(2-phosphonomethoxyethyl) adenine and 9-(S)-(3-hydroxy-2-phosphonomethoxypropyl)adenine by AMP (dAMP) kinase from L1210 cells. Biochem. Pharmacol., v.44, p.2067-2077, 1992.

MITSUYA, H.; WEINHOLD, K.J.; FURMAN, P.A.; ST CLAIR, M.H.; LEHRMAN, S.N.; GALLO, R.C.; BOLOGNESI, D.; BARRY, D.W.; BRODER, S. 3'-Azido-3'-deoxythymidine (BW A509U): an antiviral agent that inhibits the infectivity and cytopathic effect of human T-lymphotropic virus type III/lymphadenopathy associated virus in vitro. Proc. Natl. Acad. Sci. USA, v.82, p.7096-7100, 1985.

MODA, T.L.; TORRES, L.G.; CARRARA, A.E.; ANDRICOPULO, A.D. PK/DB: database for pharmacokinetic properties and predictive in silico ADME models. Bioinformatics, v.24, p.2270-2271, 2008.

MOULY, S.; LOWN, K.S.; KORNHAUSER, D.; JOSEPH, J.L.; FISKE, W.D.; BENEDEK, I.H.; WATKINS, P.B. Hepatic but not intestinal CYP3A4 displays dose-dependent induction by efavirenz in humans. Clin. Pharmacol. Therap., v.72, p.1-9, 2002.
MUTLIB, A.E.; CHEN, H.; NEMETH, G.A.; MARWALDER, J.A.; SEITZ, S.P.; GAN, L.S.; CHRIST, D.D. Identification and characterization of efavirenz metabolites by LC/MS and high field NMR. Species differences in the metabolism of efavirenz. Drug Metab. Dispos., v.27, p.1319-1333, 1999.

NARITOMI, Y.; TERASHITA, S.; KAGAYAMA, A.; SUGIYAMA, Y. Utility of hepatocytes in predicting drug metabolism: comparison of hepatic intrinsic clearance in rats and humans in vivo and in vitro. Drug Metab. Dispos., v.31, p.580-588, 2003.

NAVÉ, J.F.; ESCHBACH, A.; WOLFF-KUGEL, D.; HALAZY, S.; BALZARINI, J. Enzymatic phosphorylation and pyrophosphorylation of 2',3'-dideoxyadenosine-5' monophosphate, a key metabolite in the pathway for activation of the anti-HIV (human immunodeficiency virus) agent 2',3'-dideoxyinosine. Biochem. Pharmacol., v.48, p.1105-1112, 1994.

NUNES, E.S. Aplicação da bioconversão da zidovudina por Cunninghamella echinulata ATCC 9244 na sintese de derivados funcionalizados por carboidratos. Goiânia, 2008. 146 p. [Dissertação de Mestrado. Faculdade de Farmácia. Universidade Federal de Goiás].

OMURA, T. Forty years of cytochrome P450. Biochem. Biophys. Res. Commun., v.266, p.690-698, 1999.

PAZINI, F.; DE OLIVEIRA, V.; MENEGATTI, R.; FIGUEIRA, A.P.; FRAGA, C.A.M.; BARREIRO, E.J. Preparação de metabólitos fase I e II do derivado N-fenilpiperazínico (LASSBio-581) via bioconversão por Cunninghamella echinulata ATCC 9244 e Mortierella isabelina NRRL 1757. Rev. Eletr. Farm., v.2, supl.2, p.157-160, 2005.

PAZINI, F.; MENEGATTI, R.; SABINO, J.R.; ANDRADE, C.H.; NEVES, G.; RATES, S. M.K.; NOËL, F.; FRAGA, C.A.M.; BARREIRO, E.J.; DE OLIVEIRA, V. Design of new dopamine D2 receptor ligands: Biosynthesis and pharmacological evaluation of the hydroxylated metabolite of LASSBio-581. Bioorg. Med. Chem. Lett., v.20, p.28882891, 2010.

PELKONEN, O.; TURPEINEN, M.; UUSITALO, J.; RAUTIO, A.; RAUNIO, H. Prediction of drug metabolism and interactions on the basis of in vitro investigations. Basic Clin. Pharmacol. Toxicol., v.96, p.167-175, 2005.

PERROS, M. CCR5 antagonists for the treatment of HIV infection and AIDS. Adv. Antiviral Drug Design, v.5, p.185$212,2007$. 
PRAKASH, C.; VAZ, A.D.N. Drug metabolism: significance and challenges. In: XIE, W. (Ed.). Nuclear receptors in drug metabolism. New York: John Wiley \& Sons, Inc. 2009. Chap.1, p.1-41.

RAMANATHAN, S.; SHEN, G.; CHENG, A.; KEARNEY, B.P. Pharmacokinetics of emtricitabine, tenofovir, and GS9137 following coadministration of emtricitabine/tenofovir disoproxil fumarate and ritonavirboosted GS-9137. J. Acquir. Immune Defic. Syndr., v.45, p.274-279, 2007a.

RAMANATHAN, S.; WRIGHT, M.; WEST, S.; KEARNEY, B.P. Pharmacokinetics, metabolism and excretion of ritonavirboosted GS-9137 (elvitegravir). In: INTERNATIONAL WORKSHOP ON CLINICAL PHARMACOLOGY OF HIV THERAPY, 8., Budapest, Hungary, 2007. Abstract. Budapest: 2007b. p.30-31.

RAVITCH, J.R.; BRYANT, B.J.; REESE, M.J.; BOEHLERT, C.C.; WALSH, J.S.; MCDOWELL, J.P.; SADLER, B.M. CNS penetration of the anti-retroviral 1592 in human and animal models. In: CONFERENCE ON RETROVIRUSES AND OPPORTUNISTIC INFECTIONS, 5., 1998, Chicago, Ill. Abstract. Chicago: Foundation for Retrovirology and Human Health, 1998. p.199-199.

RISKA, P.; LAMSON, M.; MCGREGOR, T.; SABO, J.; HATTOX, S.; PAV, J.; KEIRNS, J. Disposition and biotransformation of the antiretroviral drug nevirapine in humans. Drug Metab. Dispos., v.27, p.895-901, 1999a.

RISKA, P.S.; JOSEPH, D.P.; DINALLO, R.M.; DAVIDSON, W.C.; KEIRNS, J.J.; HATTOX, S.E. Biotransformation of nevirapine, a non-nucleoside HIV-1 reverse transcriptase inhibitor, in mice, rats, rabbits, dogs, monkeys, and chimpanzees. Drug Metab. Dispos., v.27, p.1434-1447, 1999b.

RODRIGUEZ-NOVOA, S.; BARREIRO, P.; RENDÓN, A.; JIMÉNEZ-NACHER, I.; GONZÁLEZ-LAHOZ, J.; SORIANO, V. Influence of $516 \mathrm{G}>\mathrm{T}$ polymorphisms at the gene encoding the CYP450-2B6 isoenzyme on efavirenz plasma concentrations in HIV-infected subjects. Clin. Infect. Dis., v.40, p.1358-1361, 2005.

SCHINAZI, R.F.; BOUDINOT, F.D.; DOSHI, K.J.; MCCLURE, H.M. Pharmacokinetics of 3'-fluoro-3'-deoxythymidine and 3'-deoxy-2',3'-didehydrothymidine in rhesus monkeys. Antimicrob. Agents Chemother., v.34, p.1214-1219, 1990.
SMITH, R.V.; ROSAZZA, J.P. Microbial models of mammalian metabolism, aromatic hydroxylation. Arch. Biochem. Biophys., v.161, p.551-558, 1974.

SMITH, R.V.; ROSAZZA, J.P. Microbial models of mammalian metabolism. J. Pharm. Sci., v.11, p.1737-1758, 1975.

STEIGBIGEL, R.T.; COOPER, D.A.; KUMAR, P.N.; ERON, J.E.; SCHECHTER, M.; MARKOWITZ, M.; LOUTFY, M.R.; LENNOX, J.L.; GATELL, J.M.; ROCKSTROH, J.K.; KATLAMA, C.; YENI, P.; LAZZARIN, A.; CLOTET, B.; ZHAO, J.; CHEN, J.; RYAN, D.M.; RHODES, R.R.; KILLAR, J.A.; GILDE, L.R.; STROHMAIER, K.M.; MEIBOHM, A.R.; MILLER, M.D.; HAZUDA, D.J.; NESSLY, M.L.; DINUBILE, M.J.; ISAACS, R.D.; NGUYEN, B.Y.; TEPPLER, H. Raltegravir with optimized background therapy for resistant HIV-1 infection. N. Engl. J. Med., v.359, p.339-354, 2008.

ST JERNSCHANTZ, E.; VERMEULEN, N.P.E.; OOSTENBRINK C. Computational prediction of drug binding and rationalisation of selectivity towards cytochromes P450. Expert Opin. Drug Metab. Toxicol., v. 4, p.513-527, 2008.

TESTA, B.; BALMAT, A.L.; LONG, A.; JUDSON, P.N. Predicting drug metabolism - an evaluation of the expert system METEOR. Chem. Biodivers., v.2, p.872 -885, 2005.

TRAPNELL, C.B.; KLECKER, R.W.; JAMIS-DOW, C.; COLLINS, J.M. Glucuronidation of 3'-azido-3'deoxythymidine (zidovudine) by human liver microsomes: relevance to clinical pharmacokinetic interactions with atovaquone, fluconazole, methadone, and valproic acid. Antimicrob. Agents Chemother., v.42, p.1592-1596, 1998.

TRÉLUYER, J.M.; BOWERS, G.; CAZALI, N.; SONNIER, M.; REY, E.; PONS, G.; CRESTEIL, T. Oxidative metabolism of amprenavir in the human liver. effect of the CYP3A maturation. Drug Metab. Dispos., v.31, p.275-281, 2003.

UNAIDS/WORLD HEALTH ORGANIZATION. Report on the global HIV/AIDS epidemic 2008. August 2008. Geneva: Joint United Nations Programme on HIV/AIDS, p.1-356, 2008.

VEAL, G.J.; BACK, D.J. Metabolism of zidovudine. Gen. Pharmacol., v.26, p.1469-1475, 1995. 
VITORIA, M.; GRANICH, R.; GILKS, C.F.; GUNNEBERG, C.; HOSSEINI, M.; WERE, W.; RAVIGLIONE, M.; DE COCK, K.M. The global fight against HIV/AIDS, tuberculosis, and malaria: current status and future perspectives. Am. J. Clin. Pathol., v.131, p.844-848, 2009.

VOORMAN, R.L.; MAIO, S.M.; HAUER, M.J.; SANDERS, P.E.; PAYNE, N.A.; ACKLAND, M.J. Metabolism of delavirdine, a human immunodeficiency virus type-1 reverse transcriptase inhibitor, by microsomal cytochrome P450 in humans, rats, and other species: probable involvement of CYP2D6 and CYP3A. Drug Metab. Dispos., v.26, p.631-639, 1998a.

VOORMAN, R.L.; MAIO, S.M.; PAYNE, N.A.; ZHAO, Z.; KOEPLINGER, K.A.; WANG, X. Delavirdine: evidence for mechanism-based inactivation of human cytochrome $\mathrm{P} 450$ 3A. J. Pharmacol. Exp. Ther., v.287, p.381-388, 1998b.

VOORMAN, R.L.; PAYNE, N.A.; WIENKERS, L.C.; HAUER, M.J.; SANDERS, P.E. interaction of delavirdine with human liver microsomal cytochrome P450: inhibition of CYP2C9, CYP2C19, and CYP2D6. Drug Metab. Dispos., v.29, p.41-47, 2001.

WALKER, D.K.; ABEL, S.; COMBY, P.; MUIRHEAD, G.J.; NEDDERMAN, A.N.; SMITH, D.A. Species differences in the disposition of the CCR5 antagonist, UK-427,857, a new potential treatment for HIV. Drug Metab Dispos., v.33, p.587-595, 2005.

WARD, B.A.; GORSKI, J.C.; JONES, D.R.; HALL, S.D.; FLOCKHART, D.A.; DESTA, Z. The cytochrome P4502B6 (CYP2B6) is the main catalyst of efavirenz primary and secondary metabolism. Implication for HIV/AIDS therapy and utility of efavirenz as a substrate marker of CYP2B6 catalytic activity. J. Pharmacol. Exp. Ther., v.306, p.287$300,2003$.

WESTBY, M.; VAN DER RYST, E. CCR5 antagonists: hosttargeted antivirals for the treatment of HIV infection. Antiviral Chem. Chemother., v.16, p.339-354, 2005.
WU, E.; SANDOVAL, T.; ZHANG, K.; GRETTENBERGER, H.; HEE, B.; LEE, C.; WEBBER, S.; SHETTY, B. Cytochrome $\mathrm{P} 450$ isoforms involved in the metabolism of nelfinavir mesylate, an HIV-1 protease inhibitor. In: INTERNATIONAL ISSX MEETING, 5., Cairns, Australia, 1998. Abstracts. Cairns: International Society for the Study of Xenobiotics, 1998. p.110-110.

YOSHITOMI, S.; IKEMOTO, K.; TAKAHASHI, J.; MIKI, H.; NAMBA, M.; ASAHI, S. Establishment of the transformants expressing human cytochrome $\mathrm{P} 450$ subtypes in HepG2, and their applications on drug metabolism and toxicology. Toxicol. In Vitro, v.15, p.245-256, 2001.

YU, X.; CUI, D.; DAVIS, M.R. Identification of in vitro metabolites of indinavir by "intelligent automated LC-MS/ MS" (INTAMS) utilizing triple quadrupole tandem mass spectrometry J. Am. Soc. Mass Spectrom., v.10, p.175-183, 1999.

ZHANG, K.; KERR, B.; HEE, B.; TALAAT, R.; MOGER, L.; SHETTY, B.; WEBBER, S. Biotransformation of nelfinavir, a potent HIV protease inhibitor, in healthy human subjects. In: INTERNATIONAL ISSX MEETING, 5., Cairns, Australia, 1998. Abstracts. Cairns: International Society for the Study of Xenobiotics, 1998. p.112-112.

ZHANG, K.E.; WU, E.; PATICK, A.K.; KERR, B.; ZORBAS, M.; LANKFORD, A.; KOBAYASHI, T.; MAEDA, Y.; SHETTY, B.; WEBBER, S. Circulating metabolites of the human immunodeficiency virus protease inhibitor nelfinavir in humans: structural identification, levels in plasma, and antiviral activities. Antimicrob. Agents Chemother., v.45, p.1086-1093, 2001.

ZMIJEWSKI, M.; GILLESPIE, T.A.; JACKSON, D.A.; SCHMIDT, D.F.; YI, P.; KULANTHAIVEL, P. Application of biocatalysis to drug metabolism: preparation of mammalian metabolites of a biaryl-bis-sulfonamide AMPA receptor potentiator using actinoplanes missouriensis. Drug Metab. Dispos., v.34, p.925-931, 2006.

Received for publication on $10^{\text {th }}$ November 2009 Accepted for publication on $30^{\text {th }}$ March 2011 